\title{
Fate of Mercury in Synthetic Gypsum Used for Wallboard Production
}

\section{Topical Report, Task 5 Wallboard Plant Test Results}

\author{
Prepared by: \\ Jessica (Marshall) Sanderson \\ USG Corporation
}

Gary M. Blythe and

Mandi Richardson

URS Corporation

June 2006

Cooperative Agreement No: DE-FC26-04NT42080

USG Corporation

125 South Franklin Street

Chicago, Illinois 60606-4678

\author{
Prepared for: \\ Charles Miller \\ National Energy Technology Laboratory \\ U.S. Department of Energy \\ 626 Cochrans Mill Road \\ Pittsburgh, Pennsylvania 15236
}





\section{DISCLAIMER}

This report was prepared as an account of work sponsored by an agency of the United States Government. Neither the United States Government nor any agency thereof, nor any of their employees, makes any warranty, express or implied, or assumes any legal liability or responsibility for the accuracy, completeness, or usefulness of any information, apparatus, product, or process disclosed, or represents that its use would not infringe privately owned rights. Reference herein to any specific commercial product, process, or service by trade name, trademark, manufacturer, or otherwise does not necessarily constitute or imply its endorsement, recommendation, or favoring by the United States Government or any agency thereof. The views and opinions of authors expressed herein do not necessarily state or reflect those of the United States Government or any agency thereof. 


\section{ABSTRACT}

This report presents and discusses results from Task 5 of the study "Fate of Mercury in Synthetic Gypsum Used for Wallboard Production,” performed at a full-scale commercial wallboard plant. Synthetic gypsum produced by wet flue gas desulfurization (FGD) systems on coal-fired power plants is commonly used in the manufacture of wallboard. The FGD process is used to control the sulfur dioxide emissions which would result in acid rain if not controlled. This practice has long benefited the environment by recycling the FGD gypsum byproduct, which is becoming available in increasing quantities, decreasing the need to landfill this material, and increasing the sustainable design of the wallboard product. However, new concerns have arisen as recent mercury control strategies developed for power plants involve the capture of mercury in FGD systems. The objective of this study is to determine whether any mercury is released into the atmosphere when the synthetic gypsum material is used as a feedstock for wallboard production. The project is being co-funded by the U.S. DOE National Energy Technology Laboratory (Cooperative Agreement DE-FC26-04NT42080), USG Corporation, and EPRI. USG Corporation is the prime contractor, and URS Group is a subcontractor.

The project scope includes five discrete tasks, each conducted at various USG wallboard plants using synthetic gypsum from different FGD systems. The five tasks were to include 1) a baseline test, then variations representing differing power plant 2) emissions control configurations, 3) treatment of fine gypsum particles, 4) coal types, and 5) FGD reagent types. However, Task 5, which was to evaluate gypsum produced from an alternate FGD reagent, could not be conducted as planned. Instead, Task 5 was conducted at conditions similar to a previous task, Task 3, although with gypsum from an alternate FGD system.

In this project, process stacks in the wallboard plant have been sampled using the Ontario Hydro method. The stack locations sampled for each task include a dryer for the wet gypsum as it enters the plant and a gypsum calciner. The stack of the dryer for the wet wallboard product was also tested as part of this task, and was tested as part of Tasks 1 and 4. Also at each site, in-stream process samples were collected and analyzed for mercury concentration before and after each significant step in wallboard production. The Ontario Hydro results, process sample mercury concentration data, and process data were used to construct mercury mass balances across the wallboard plants.

Task 5 was conducted at a wallboard plant processing synthetic gypsum from a power plant that fires Eastern bituminous coal. The power plant is equipped with a selective catalytic reduction (SCR) system for $\mathrm{NO}_{\mathrm{X}}$ emissions control, but the SCR was bypassed during the time period the gypsum tested was produced. The power plant has a single-loop, open spray tower, limestone reagent FGD system, with forced oxidation conducted in a reaction tank integral with the FGD absorber. The FGD system has gypsum fines blow down as part of the dewatering step. Gypsum fines blow down is believed to be an important variable that impacts the amount of mercury in the gypsum byproduct and possibly its stability during the wallboard process.

The results of the Task 5 stack testing, as measured by the Ontario Hydro method, detected that an average of 51\% of the incoming mercury in the FGD gypsum was emitted during wallboard production. These losses were distributed as $2 \%$ or less each across the wet gypsum dryer and 
product wallboard dryer, and about $50 \%$ across the gypsum calciner. Emissions were similar to what Task 3 results showed, on both a percentage and a mass basis, for gypsum produced by a power plant firing bituminous coal and also having gypsum fines blow down as part of the FGD dewatering scheme.

As was seen in the Task 1 through 4 results, most of the mercury detected in the stack testing on the wet gypsum dryer and kettle calciner was in the form of elemental mercury. In the wallboard dryer kiln, a more significant percentage of the mercury detected was in the oxidized form, particularly from the stack near the product discharge end of the kiln. However, this represented a very small percentage of the overall mercury loss. 


\section{TABLE OF CONTENTS}

Page

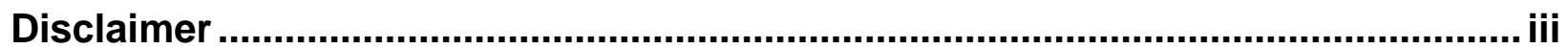

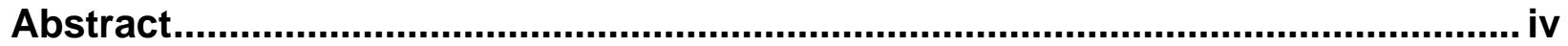

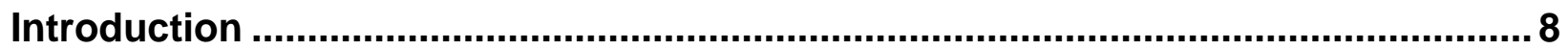

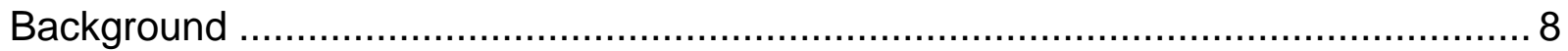

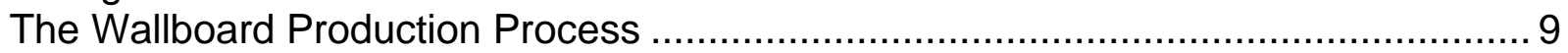

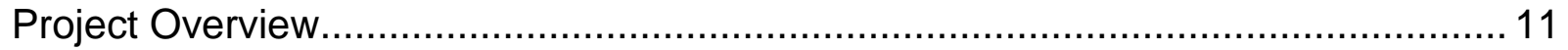

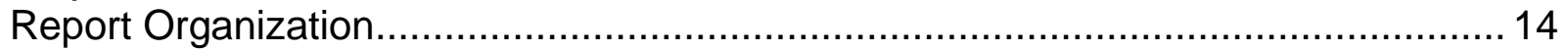

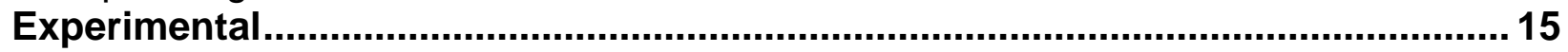

Rationale for Selecting the Synthetic Gypsum Tested .................................. 15

Commercial Wallboard Plant Test Procedures ............................................ 16

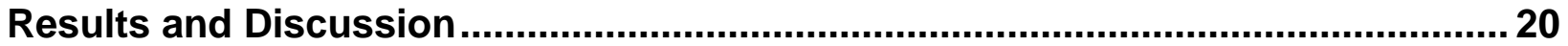

Gypsum and Process Sample Mercury Analysis Results ................................ 20

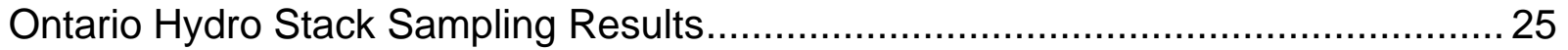

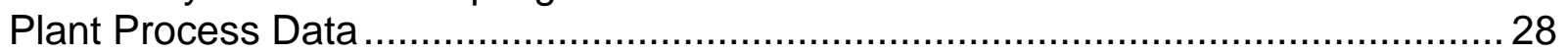

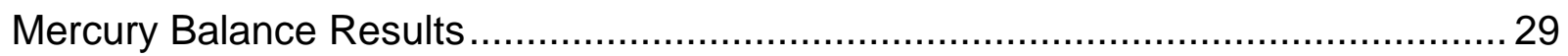

Summary of Mercury Loss Calculations .................................................. 32

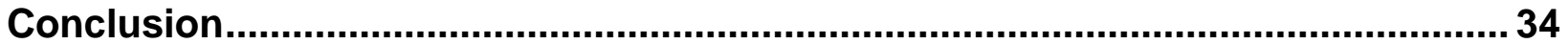

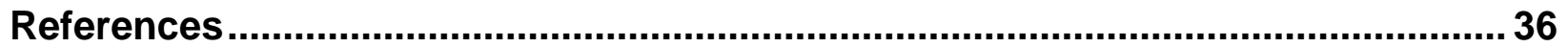




\section{LIST OF FIGURES}

Figure 1. Simplified Schematic of the Wallboard Production Process Using Synthetic

Gypsum Feedstock.......................................................................... 10

Figure 2. Schematic of Wallboard Plant 4 Showing Sampling Locations ..................... 17

\section{LIST OF TABLES}

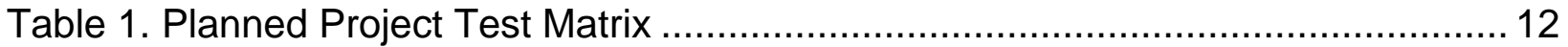

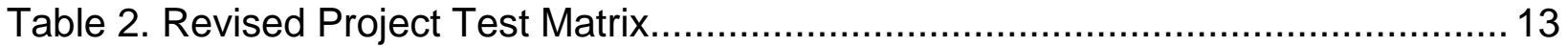

Table 3. Task 5 Raw Gypsum and Mill Process Sample Mercury and Moisture

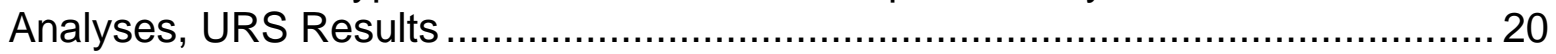

Table 4. Task 5 Mill Line Process Sample Characterization, USG Results................... 21

Table 5. Task 5 Board-line Process Sample Analyses, URS Results ……...................22

Table 6. Task 5 Board Line Process Sample Characterization, USG Results................22

Table 7. Task 5 Ontario Hydro Results - Summary of Exhaust Gas Conditions ............ 25

Table 8. Task 5 Ontario Hydro Results - Speciated Mercury Emissions Data ............... 27

Table 9. Task 5 Mill Test Process Conditions ......................................................... 28

Table 10. Task 4 Board-line Test Process Conditions................................................. 28

Table 11. Task 5 Mercury Balance Results for the Mill Test .................................... 29

Table 12. Task 5 Mercury Balance Results for the Board-line Test ........................... 31

Table 13. Summary of Task 5 Overall Mercury Loss During Wallboard Production, Calculated by Two Methods 


\section{INTRODUCTION}

This report presents and discusses results from Task 5 of the study "Fate of Mercury in Synthetic Gypsum Used for Wallboard Production,” performed at a full-scale commercial wallboard plant. The objective of this project is to measure whether any mercury evolves from synthetic gypsum produced by wet flue gas desulfurization (FGD) systems on coal-fired power plants, when that material is used as a feedstock for wallboard production. The project is being co-funded by the U.S. DOE National Energy Technology Laboratory (Cooperative Agreement DE-FC2604NT42080), USG Corporation, and EPRI. USG Corporation is the prime contractor, and URS Group is a subcontractor.

\section{Background}

To address concerns about air quality, the U.S. Congress passed the Clean Air Act Amendments of 1990, which placed significant restrictions on sulfur dioxide emissions from coal-fired power plants. To reduce sulfur dioxide emissions and meet the Clean Air Act standards, many electric utilities installed wet FGD systems on their coal-fired plants. These FGD systems combine the sulfur dioxide gases released during coal combustion with a sorbent such as limestone or lime. In many of these wet FGD systems, the resulting byproduct is oxidized to produce synthetic gypsum. The synthetic gypsum produced is commonly used as a feedstock for wallboard production. The reuse of the synthetic gypsum is environmentally beneficial and is also economically attractive for both the power and wallboard industries. The Clean Air Interstate Rule, signed by the U.S. EPA in March 2005, will further regulate sulfur dioxide emissions. Greater amounts of synthetic gypsum will be created, potentially causing a large increase in the volume of this material to going to landfills. Establishing wallboard manufacturing plants near both power plants and population centers can reduce the quantity land filled, while increasing the sustainable design of the wallboard product by reducing transportation and use of fossil fuels.

A number of mercury control strategy plans for U.S. coal-fired power generating plants involve the capture of oxidized mercury from flue gases treated by wet FGD systems. For example, in finalizing the Clean Air Mercury Rule on March 15, 2005, the U.S. EPA recognized mercury emissions reduction "co-benefits" possible for coal-fired plants that are equipped with selective catalytic reduction (SCR) for $\mathrm{NO}_{\mathrm{X}}$ control and wet FGD systems for $\mathrm{SO}_{2}$ control. SCR systems on bituminous coal fired plants have been observed to oxidize most of the elemental mercury in the SCR inlet gas. Also, a number of proposed mercury control processes involve using lowtemperature catalysts or injected chemicals to oxidize elemental mercury and promote increased mercury removal across FGD systems.

For these processes to be effective at overall mercury control, the mercury must stay in the FGD byproducts and not be re-emitted to the atmosphere or into ground water. Measurements by URS Group and others have indicated that most of the mercury scrubbed from flue gases in most U.S. wet FGD systems ends up in the solid byproducts. Little mercury is typically found in the FGD liquors. Thus, mercury stability in FGD solid byproducts is an important aspect of mercury capture in FGD systems. 
Most FGD systems use lime or limestone reagent and employ forced oxidation to produce gypsum $\left(\mathrm{CaSO}_{4} \cdot 2 \mathrm{H}_{2} \mathrm{O}\right)$ as the solid byproduct. Much of the gypsum byproduct is reused, primarily as a feedstock for wallboard manufacturing. Those that do not produce gypsum instead produce a calcium sulfite hemihydrate $\left(\mathrm{CaSO}_{3} \bullet \frac{1}{2} \mathrm{H}_{2} \mathrm{O}\right)$ byproduct. Most calcium sulfite byproducts are land filled, although some is reused as mine fill.

Approximately 70\% of all of the FGD byproduct reuse in the U.S. is gypsum used as wallboard feedstock. During the year 2005, synthetic gypsum from FGD systems was expected to represent $30 \%$ of the U.S. wallboard plant feedstock.

This raises new technical questions: What is the fate of mercury in synthetic gypsum in the wallboard plant process? How much mercury is released into the atmosphere during the production of wallboard using synthetic gypsum? Is the amount of mercury released counterproductive to controlling mercury emissions from coal-fired power plants?

Even if mercury is not released in significant quantities during wallboard production, there remains a question as to the stability of mercury in the wallboard product. As an example, at the end of its product life cycle, most wallboard ends up in municipal landfills. What is the stability of mercury in wallboard produced from synthetic gypsum? Will the mercury leach into the acidic aqueous environment in a municipal landfill? This project is intended to collect data from commercial wallboard plants processing FGD synthetic gypsum to help answer these questions.

\section{The Wallboard Production Process}

Figure 1 shows an overview of the wallboard production process. In the process, synthetic gypsum is dried to produce "land plaster," which is gypsum that contains no free moisture, only chemically bound waters of hydration. The land plaster is then calcined to produce the "beta" form of calcium sulfate hemihydrate according to the following chemical reaction:

$$
2 \mathrm{CaSO}_{4} \cdot 2 \mathrm{H}_{2} \mathrm{O}+\text { heat } \rightarrow 2 \mathrm{CaSO}_{4} \bullet \frac{1 / 2}{2} \mathrm{H}_{2} \mathrm{O}+3 \mathrm{H}_{2} \mathrm{O}
$$

The beta hemihydrate is also commonly called "stucco" or "plaster of Paris." The stucco is subsequently mixed with water and a number of additives to form a slurry that is extruded between two sheets of paper to form the wallboard. The hemihydrate re-hydrates to form gypsum by the reverse of the reaction shown above. This re-hydration consumes much of the water in the slurry, and causes the gypsum formed to set up as a cohesive solid. The wet board travels down a conveyor belt while it is setting up. After adequate residence time to set up, the board is cut to approximate length, and then dried to remove free moisture (excess water not consumed by the re-hydration reaction). The dried product is cut to final length then stack for shipping.

The initial gypsum drying and calcining steps described above occur in a section of the plant called the mill. The dryers are typically direct gas fired. Their purpose is to remove the free moisture in the synthetic gypsum (typically 8 to $12 \%$ by weight of the raw material) prior to calcining. The dryers consequently operate at temperatures well below the gypsum calcining temperature. The solids are dried by direct contact between the wet particles and the hot 


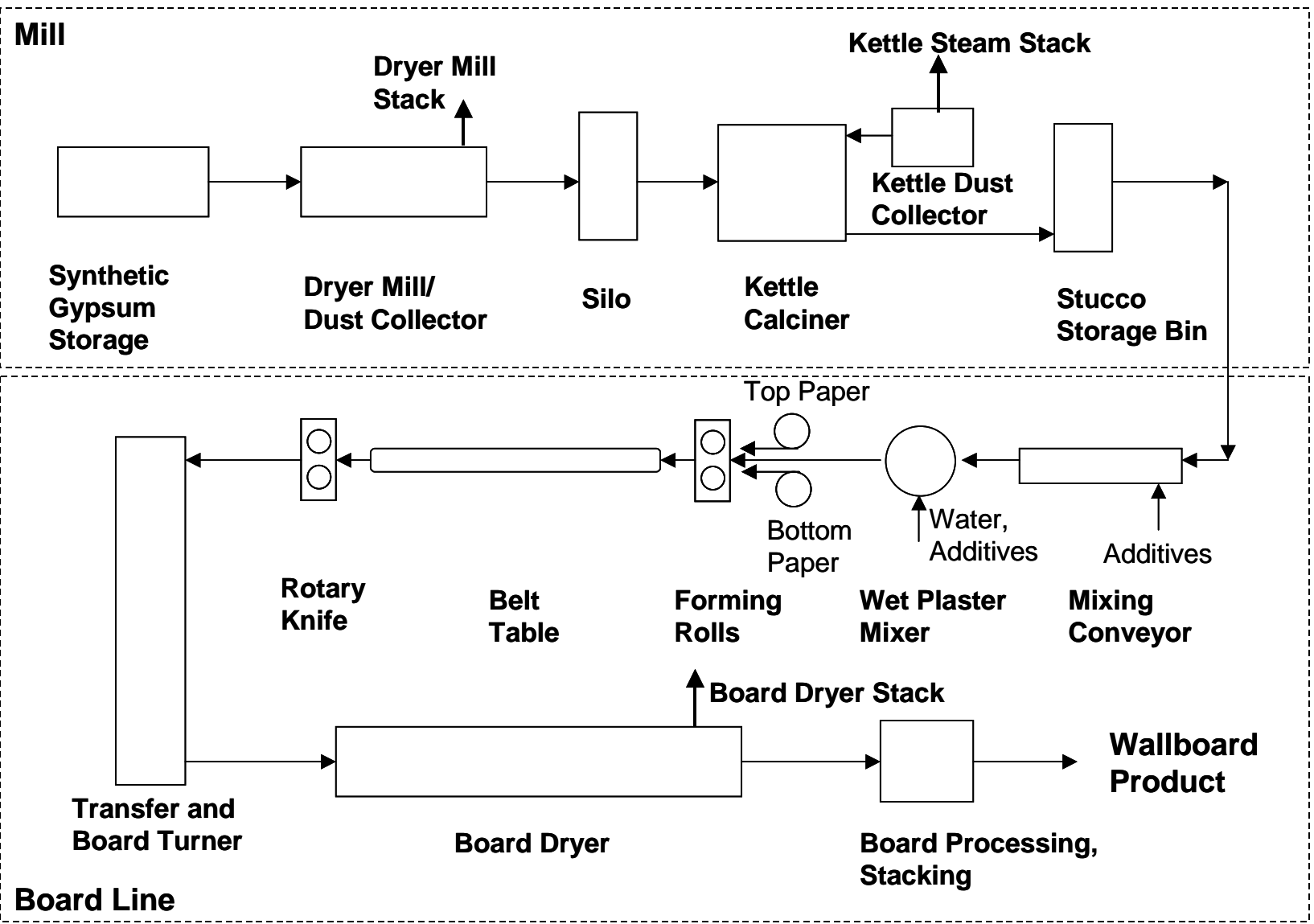

Figure 1. Simplified Schematic of the Wallboard Production Process Using Synthetic Gypsum Feedstock.

flue gas. The moisture-free synthetic gypsum (land plaster) is collected in mechanical collectors or a fabric filter and placed in intermediate storage silos prior to feeding to the calciners.

In the calcining step, the solids temperature must be raised above $262^{\circ} \mathrm{F}$ to promote release of 1 $1 / 2$ waters of hydration, but must be kept below $325^{\circ} \mathrm{F}$ to avoid forming anhydrous calcium sulfate (no remaining waters of hydration). The calciners used at the wallboard plant tested are indirectfired kettle calciners, so the vent gas from the solids side of the kettle is primarily a mixture of steam and air. A kettle calciner dust collector removes fine stucco particles from this vent gas. The recovered fine particles are added to the kettle calciner product. The stucco leaving the kettle is cooled and placed in a bin for intermediate storage, to provide a buffer between the mill and board line.

In the board line, the cooled stucco from the silo is fed to a mixer, where "gauging" water is added to form a viscous slurry. The gauging water is typically of high quality (e.g., potable water). A number of proprietary additives are mixed with the wet slurry produced from the stucco.

This wet slurry is continuously extruded between two sheets of paper that are fed from rolls above and below the extruder. One type of paper is used for the face of the wallboard product 
and another for the back. The formed board travels down a long conveyor belt that provides residence time for the stucco to re-hydrate and take a set. At the end of this belt, the formed board is cut and inverted so the face paper is facing up.

The board then enters a dryer. The dryer is zoned to operate over a range of temperatures, typically over $400^{\circ} \mathrm{F}$ at the dryer entrance and about $200^{\circ} \mathrm{F}$ at the exit. However, the board residence time in the dryer is controlled to limit the temperature of the dried board. This temperature must be limited to avoid any of the set-up solids re-calcining to the hemihydrate form. Thus, the bulk of the rehydrated gypsum solids in the wallboard product stay well below the temperature that would result in conversion to hemihydrate. From the dryer, the dried board is cut to final size, has end tape applied, and is stacked for shipment.

Any potential mercury losses during the wallboard process are assumed to occur during the thermal processes, with losses most likely during the calcining step. The synthetic gypsum particles are raised to the highest temperature in the process during this step (above $262^{\circ} \mathrm{F}$ ). Losses are also possible from the synthetic gypsum dryer and the finished wallboard dryer, although the maximum temperatures to which the gypsum is raised are lower in the dryers (approximately $170^{\circ} \mathrm{F}$ to $230^{\circ} \mathrm{F}$ ).

\section{Project Overview}

This project is intended to provide information about the fate of mercury in synthetic gypsum produced by FGD systems on coal-fired power plants, when used as feedstock for wallboard production. Solid samples from various locations in the wallboard process, including the wallboard product, are being collected and analyzed for mercury content. Simultaneous flue gas measurements are being made using the Ontario Hydro method to quantify any mercury releases to the atmosphere during wallboard production. Most of the testing has concentrated on the mill processes where the synthetic gypsum is dried and calcined. Any potential mercury releases from the synthetic gypsum solids are thought to result from thermal desorption. It is in the mill portion of the process where the feedstock sees the highest process temperatures and where the evolution of waters of hydration may promote mercury desorption.

Initially, a limited amount of testing was to be conducted in the downstream board line, where the calcined gypsum is slurried, mixed with proprietary additives and formed into wallboard. The project plan was for the board dryer kiln stack flue gas to only be measured for mercury content at the first test site. Lesser mercury release was expected in the board dryer kiln because it is downstream of the mill, and the rehydrated gypsum solids typically see lower temperatures than in the mill. However, once results were available from Task 1, showing appreciable mercury loss from the board dryer kiln stack, stack testing for the board dryer kiln was added to the project scope for Tasks 4 and 5 .

The solid and flue gas mercury concentration and plant process data are being used to calculate mercury balances around the operating wallboard plant, to help confirm measured mercury loss rates.

Samples of each synthetic gypsum tested are being evaluated in laboratory simulated calcining tests to provide comparison data and evaluate a lab technique for screening synthetic gypsum 
samples. Also, wallboard produced from synthetic gypsum will be leached according to the Toxicity Characteristic Leaching Procedure (TCLP) to provide an indication whether wallboard disposed of in municipal landfills will have a tendency to release mercury into groundwater. The TCLP test was chosen based on current regulations, however future studies may include a more comprehensive set of leachate procedures.

The project has investigated wallboard produced from a variety of synthetic gypsum sources, all from FGD systems on coal-fired power plants, but from different coal types, power plant emissions control configurations and FGD conditions. The project is structured in five tasks. As shown in Table 1, each involves one commercial wallboard plant test. This report summarizes the results from Task 5.

Table 1. Planned Project Test Matrix

\begin{tabular}{|c|c|c|c|c|c|}
\hline Task & 1 & 2 & 3 & 4 & 5 \\
\hline \multicolumn{6}{|c|}{ Synthetic Gypsum Source: } \\
\hline Power Plant & A & A & $B$ & $\mathrm{C}$ & $\mathrm{D}$ \\
\hline Coal Type & $\begin{array}{l}\text { High sulfur } \\
\text { bituminous }\end{array}$ & $\begin{array}{l}\text { High sulfur } \\
\text { bituminous }\end{array}$ & $\begin{array}{l}\text { High sulfur } \\
\text { bituminous }\end{array}$ & Texas lignite & $\begin{array}{l}\text { High sulfur } \\
\text { bituminous }\end{array}$ \\
\hline FGD Reagent & Limestone & Limestone & Limestone & Limestone & Lime \\
\hline Forced Oxidation Mode & In Situ & In Situ & In Situ & In Situ & External \\
\hline $\begin{array}{l}\text { Gypsum Fines Blow } \\
\text { Down? }\end{array}$ & No & No & Yes & No & Yes \\
\hline SCR Operating? & Yes & No & Yes & No & TBD* \\
\hline $\begin{array}{l}\text { USG Wallboard Plant } \\
\text { Tested }\end{array}$ & 1 & 1 & 2 & 3 & 1 \\
\hline
\end{tabular}

*To be determined later based on the time of the year of the test

To investigate five different synthetic gypsum feedstocks, testing was planned to be conducted at three different USG wallboard plants, since no one plant uses all five as a feedstock. The relationship between synthetic gypsum types and USG plants proposed for investigation is shown in Table 1. Note that the power plants and USG wallboard plants are not identified by name, only by letter or number codes, in accordance with an agreement for anonymity at the beginning of the project.

The first four tasks included tests on synthetic gypsum feedstocks produced from:

- A power plant that fires medium- to high-sulfur bituminous coal and that has an SCR for $\mathrm{NO}_{\mathrm{x}}$ control, an LSFO FGD system that produces wallboard grade gypsum byproduct, and does not have gypsum fines blow down.

- The same plant included in Task 1, but without the SCR operating (SCR catalyst bypassed). Since SCR catalysts have been observed to promote mercury oxidation, taking the SCR out of service may impact the amount of mercury captured in the FGD byproduct and could impact mercury losses during wallboard production,

- A high-sulfur, bituminous LSFO plant with SCR that employs gypsum fines blow down, and 
- A plant that fires Texas lignite rather Eastern bituminous coal, and that does not have SCR.

Each of these variables was thought to impact the amount of mercury in the synthetic gypsum feedstock and/or possibly impact the stability of that mercury in the wallboard production process.

As shown in the table, the project plan was for the fifth task to investigate a synthetic gypsum feedstock produced by a power plant that fires Eastern high-sulfur bituminous coal and that has an SCR for $\mathrm{NO}_{\mathrm{x}}$ control, but it was not certain whether the SCR would be in operation when the gypsum to be tested would be produced. The major variable to be evaluated in Task 5 was the effect of FGD reagent. While the other four tasks tested gypsums produced from FGD systems that use limestone reagent with in situ (in the FGD absorber reaction tank) forced oxidation, Task 5 was to test gypsum produced from an FGD system that uses lime reagent and forced oxidizes the byproduct in a tank external to the absorber loop.

However, the logistics for conducting Task 5 using gypsum from Power Plant D proved to be difficult. USG Wallboard Plant 1 normally processes a blend of gypsum from Power Plants A and D, with Power Plant D material comprising less than half. And, since the gypsum from Power Plant A was expected to have a higher mercury content than that from Power Plant D, a blend of the two was deemed to be inappropriate for Task 5. Because of space limitations at the wallboard plant, it proved very difficult to stockpile enough material to allow the wallboard plant to gradually transition to processing $100 \%$ material from Power Plant D. After an extended period over which the wallboard plant unsuccessfully attempted to achieve that goal, it was decided to modify the project plan for Task 5.

The highest mercury losses measured in the first four tasks were in Task 3, where the gypsum was produced by a power plant that fires high-sulfur Eastern bituminous coal, has an SCR in service, uses limestone FGD reagent, and incorporates gypsum fines blow down as part of the gypsum dewatering scheme. It was decided to test a second system with a similar configuration in Task 5 , to see if similarly high mercury losses would be measured. Table 2 shows the revised project test matrix. One difference between Tasks 3 and 5 is that for Task 5, the SCR was not in service (bypassed) on the power plant that produced the gypsum. However, based on results from Tasks 1 and 2, this was not thought to be a significant factor.

Table 2. Revised Project Test Matrix

\begin{tabular}{|l|c|c|c|c|c|}
\hline Task & $\mathbf{1}$ & $\mathbf{2}$ & $\mathbf{3}$ & $\mathbf{4}$ & $\mathbf{5}$ \\
\hline Synthetic Gypsum Source: & \multicolumn{4}{|c|}{} & \multicolumn{2}{|c|}{} \\
\hline Power Plant & A & A & B & C & E \\
\hline Coal Type & $\begin{array}{l}\text { High sulfur } \\
\text { bituminous }\end{array}$ & $\begin{array}{l}\text { High sulfur } \\
\text { bituminous }\end{array}$ & $\begin{array}{l}\text { High sulfur } \\
\text { bituminous }\end{array}$ & Texas lignite & $\begin{array}{c}\text { High sulfur } \\
\text { bituminous }\end{array}$ \\
\hline FGD Reagent & Limestone & Limestone & Limestone & Limestone & Limestone \\
\hline Forced Oxidation Mode & In Situ & In Situ & In Situ & In Situ & In Situ \\
\hline $\begin{array}{l}\text { Gypsum Fines Blow } \\
\text { Down? }\end{array}$ & No & No & Yes & No & Yes \\
\hline SCR Operating? & Yes & No & Yes & No & No \\
\hline $\begin{array}{l}\text { USG Wallboard Plant } \\
\text { Tested }\end{array}$ & 1 & 1 & 2 & 3 & 4 \\
\hline
\end{tabular}


This report presents and discusses the results of the wallboard plant testing conducted as part of Task 5, including Ontario Hydro measurements in the dryer mill, kettle calciner, and board kiln, process sample mercury content, process data, and mercury balance results. Previous reports have presented and discussed the results of the tests conducted at part of Tasks 1 through $4^{1,2,3,4}$. Planned laboratory evaluations, including simulated gypsum calcining tests and mercury leaching from wallboard product samples by TCLP, have not all been completed yet and will be reported later in the project.

\section{Report Organization}

The remainder of this report is organized into four sections: Experimental, Results and Discussion, Conclusion, and References. The section entitled Experimental describes the experimental methods used to conduct the mercury testing at a commercial wallboard plant as part of Task 4, including stack testing, process sampling, and off-site chemical analyses. The Results and Discussion section presents results from the stack testing, process sample analyses, process data collected, and mercury balance calculations. The Conclusion section provides preliminary conclusions that can be made from the results of this commercial wallboard plant mercury test. 


\section{EXPERIMENTAL}

A description of the project test matrix was provided in the Introduction section. This section begins with an explanation of the rationale used for choosing this particular FGD synthetic gypsum as a wallboard plant feedstock for a test condition. The remainder of the section presents details of how the wallboard plant mercury test was conducted, including stack testing by the Ontario Hydro method, process sample collection and analyses, and process data collection.

\section{Rationale for Selecting the Synthetic Gypsum Tested}

Gypsum fines blow down is believed to be an important variable that impacts the amount of mercury in the gypsum byproduct and possibly its stability during the wallboard process. Most synthetic gypsum used as a wallboard plant feedstock is subject to a number of quality control specifications by the wallboard manufacturer, including maximum moisture content, minimum gypsum content, maximum chloride content, and particle size distribution. A number of FGD variables affect the ability to meet the solids particle size distribution specification. These variables include the gypsum crystal residence time in the FGD absorber loop, FGD reagent chemical composition, and the amount of physical abrasion to which the crystals are exposed as they are recirculated and dewatered. Some FGD systems cannot meet the wallboard manufacturer's particle size specification unless they separate a portion of the byproduct containing the smallest particle sizes. This separation is typically accomplished with hydrocyclones. The separated fines are either discarded or sold for other uses. Other plants need to purge a portion of the hydrocyclone overflow as a means of limiting chloride buildup in the FGD liquor. These plants blow down gypsum fines as part of the chloride purge. In still other plants, there is no need to separate the fines and/or purge chlorides, and the fines are included in the byproduct sent to the wallboard plant.

Laboratory testing conducted by URS for EPRI indicated that the mercury concentration in gypsum fines can be as much as an order of magnitude higher than in the larger particles. ${ }^{5}$ This suggests that mercury precipitates and/or adsorbs at the surfaces of fine particles in the gypsum, since the fines have a much higher surface area to mass ratio than larger particles. Many of the fine particles represent impurities that enter the FGD system with fly ash in the flue gas or with the FGD reagent. Upwards of half of the mercury removed by the FGD system can be in the fines. Fines blow down therefore significantly lowers the mercury concentration in the synthetic gypsum byproduct going to the wallboard plant.

Since Power Plant E providing the feedstock for the current, Task 5 test employs fines blow down, it was expected to have lower mercury content in the synthetic gypsum byproduct than would a similar plant without fines blow down (e.g., Power Plant A, whose byproduct was tested as part of Tasks 1 and 2). And, as mentioned in the previous section, results from Task 3 suggested that a significant percentage of the mercury in the gypsum from Power Plant E might be emitted during wallboard production. Task 5 was conducted to determine if these hypotheses would be confirmed. 


\section{Commercial Wallboard Plant Test Procedures}

Commercial wallboard plants often operate with a blend of feedstock from a number of FGD systems. Rarely does one power plant generate enough synthetic gypsum to feed the entire production of a modern wallboard plant, so most plants process synthetic gypsum from two or more power plants. Each synthetic gypsum has unique processing conditions within the wallboard plant process. Therefore, to minimize excessive swings in wallboard plant operating conditions, most plants blend the available feedstock to produce an "average" material for processing.

For this test, the wallboard plant was operated on $100 \%$ feedstock from Power Plant E, as it would be more difficult to elucidate the effects of power plant and FGD variables on mercury losses during wallboard production if synthetic gypsum blends were being processed during measurements. Also, the feedstock to the mill typically contains recycled material, which can include recycled wallboard, wallboard samples, material recycled from the calciner during shut downs, etc. Because recycle consists of material from a variety of sources, it was felt that recycle would add variability to the incoming feed mercury concentration and possibly its stability. Therefore, the wallboard plant test was conducted with no recycle feed to the plant during any of the three sampling runs.

Two days of wallboard plant testing were conducted in USG Wallboard Plant 4, with the first day testing in the mill and the second day in the board line as described below. Figure 2 illustrates the wallboard production process. Process streams that were sampled as part of the test, as described below, are marked with "S" followed by a number that represents a sample location. The sample numbers are used in the data tables later in the report.

\section{Days 1 and 2 - Mill Testing}

\section{Stack Sampling}

On the first test day, simultaneous gas measurements were conducted using the Ontario Hydro method (ASTM D6784-02) on a wet gypsum dryer (a Williams mill, called the dryer mill in this report) stack and a downstream kettle calciner dust collector (steam) stack. Wallboard Plant 4 has one dryer mill and two operating kettle calciners. Only one of the two kettle calciners was sampled. As noted in the previous Topical Reports for this project, the Ontario Hydro method was modified slightly for sampling at the kettle calciner steam stack. This modification is described below. Triplicate runs were made at each of these two locations.

The kettle calciners are indirect-fired vessels. The gaseous stream from the calciner that could contain mercury from the synthetic gypsum is the "steam stack," which is a mixture of the water calcined from the gypsum when forming stucco $\left(\mathrm{CaSO}_{4} \cdot 1 / 2 \mathrm{H}_{2} \mathrm{O}\right)$ and aeration air introduced at the bottom of the kettle. The other stack from the kettle calciner contains the flue gas from the burners, which are natural gas fired. This stream is not expected to have measurable mercury content, nor would it be attributable to mercury in the land plaster feed. 


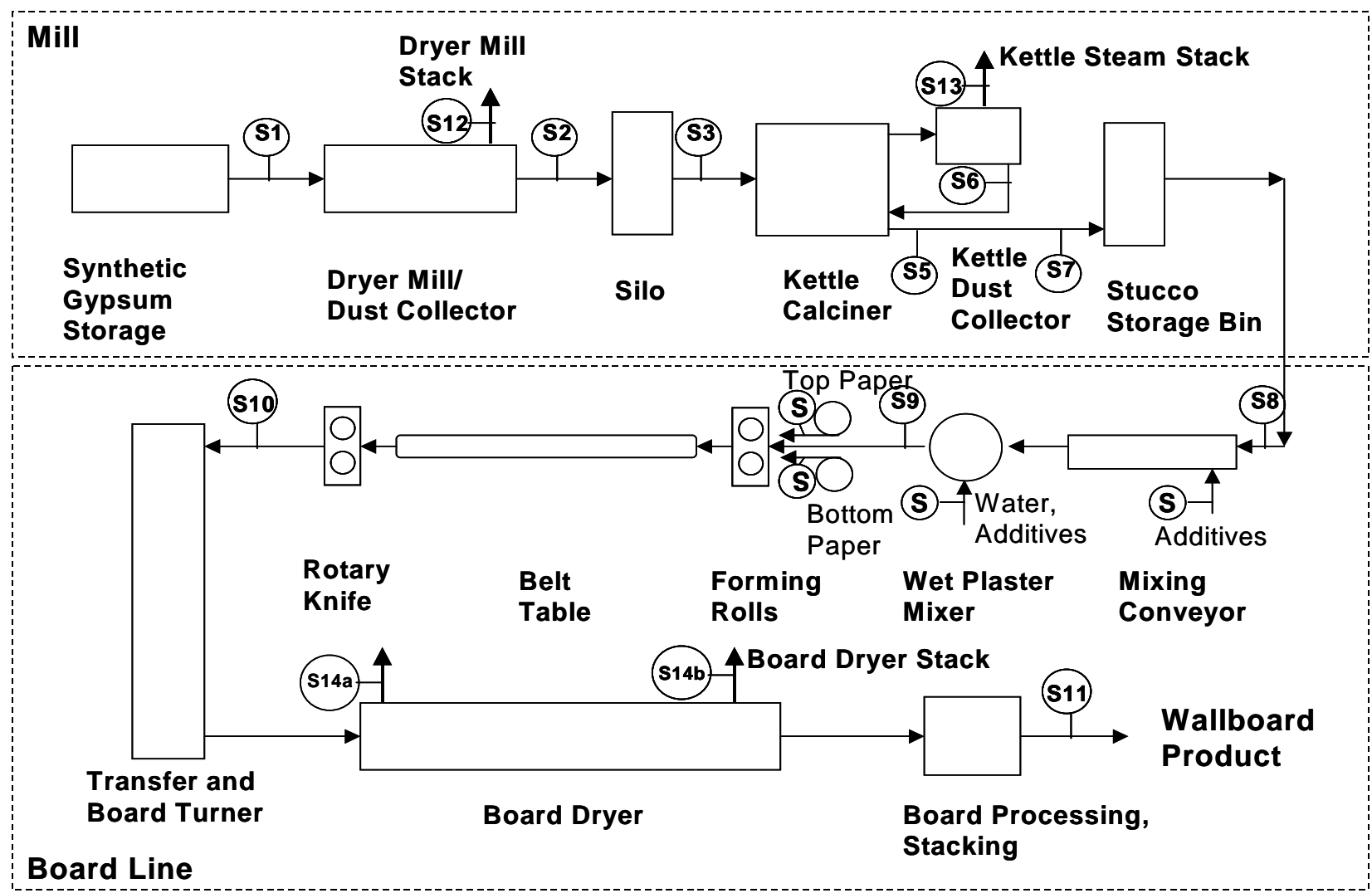

Figure 2. Schematic of Wallboard Plant 4 Showing Sampling Locations

The steam stack gas is significantly wetter than coal flue gases, for which the Ontario Hydro method was developed and validated. Consequently, the method was modified slightly to ensure proper sampling and speciation under these conditions, by adding impinger volume to the train to collect the large amount of condensed moisture expected, and by reducing the run time to limit the total amount of water collected. The dryer mill is direct fired, so its stack gas is a true flue gas and the standard Ontario Hydro Method was appropriate for sampling this stream.

\section{Process Sampling}

During each of the three runs, process samples were collected from the dryer feed solids, dryer product solids (land plaster to intermediate silo), calciner feed (land plaster from intermediate silo), and the stucco as it is fed to the product stucco storage bin. These four streams represent the feeds and products for the dryer mill and kettle calciner. Two additional solid stream samples were collected: the solids collected from the kettle calciner dust collector, which are blended with the calciner product, and calciner product stucco prior to having the dust collecter solids added. These two additional sample types were analyzed and reported for mercury concentration, but these data were not used for mercury balance or mercury loss calculations.

All six of these process solids samples were collected as "grab" samples during the middle part of each Ontario Hydro run. No attempt was made to collect time-integrated samples, e.g., by collecting small sample aliquots at periodic intervals throughout the Ontario Hydro sampling 
periods and compositing the aliquots into a single sample. Based on results from the previous tasks, it was expected that the incoming raw gypsum would be homogenous enough that one grab sample per run would adequately represent the feedstock and other process solids. These 18 grab samples were subsequently analyzed for mercury content, moisture content, and other parameters.

Process data were collected for each of the three runs, including dryer and calciner feeder speeds and operating temperatures. These data were recorded by mill operators periodically during the sampling periods.

\section{Day 2 - Board-Line Testing}

\section{Stack Sampling}

According to the original project plan, no stack sampling was to be conducted on the board dryer kiln stack as part of Task 5; only process samples were to be collected. However, because the mercury losses from the board dryer kiln stack measured as part of Task 1 were higher than expected, ${ }^{1}$ it was decided to add board dryer kiln stack measurements to the scope of Task 5.

On the second test day, triplicate Ontario Hydro Method measurements were conducted on the board dryer kiln stack gas. The timing of the second day measurements was to approximately correspond with the processing of stucco material calcined the previous day, taking into account the residence time in the stucco storage bin between the mill and board line.

The board dryer kiln at Wallboard Plant 4 is somewhat different than at Wallboard Plants 1 and 2 (Tasks 1 through 3), but similar to that at Wallboard Plant 3 (Task 4) in that it has two flue gas stacks, one on the wet wallboard feed end (the "wet end") and one on the wallboard product end (the "dry end"). Consequently, during each board dryer kiln sampling run, two Ontario Hydro measurement runs were conducted simultaneously, one on each stack.

\section{Process Sampling}

During each of the triplicate Ontario Hydro runs, samples were collected of the feed stucco, the slurry fed to the board forming machine, and the wet and dry product wallboard.

Water and a number of proprietary additives are added to the stucco when mixing the slurry prior to the board forming step. The water, each of these additives, and the paper used during board forming were also sampled once during the test, to evaluate their impact on the mercury content of the slurry and the wallboard. Triplicate samples of the additives and paper were not deemed to be necessary, as each is fed from a large silo, storage tank, or rolls that should have been relatively homogenous over the course of the three Ontario Hydro runs. Note that, because the composition and dosages of the additives are considered proprietary, the results from sampling additives and the paper are reported only as their percent contribution to the total mercury content in the wet board. No individual additive feed rate or mercury concentration data are reported, nor are the chemical compositions or names of these additives. 
As for the mill testing effort, key process data were collected throughout each sampling run. These data were manually recorded from process control software screens intermittently during each of the three Ontario Hydro runs. For the board line, these data include the stucco feed rate, water and additive feed rates (not included in this report), paper thickness and weight, board production rate, and the dryer flue gas temperatures.

The board-line sampling was confounded somewhat by things that happened during the day. During Ontario Hydro run 1, the board line was shut down for a period due to an upset in the slurry feed system. During the second Ontario Hydro run, the board line was switched from producing $5 / 8$-inch-thick wallboard to $1 / 2$-inch-thick wallboard, and was shut down briefly due to an upset in the paper feed system. The third Ontario Hydro run was completed with no upsets in the board line while producing $1 / 2$-inch board. The data reduction effort described later in this report accounted for the upsets during the first two Ontario Hydro runs to the extent possible.

As the two-day sampling effort was completed, all process and Ontario Hydro method samples were recovered, stabilized, and labeled, then shipped to URS and USG laboratories for analyses. Method blanks and reagent blanks for the Ontario Hydro method samples were included with the sample sets as a quality assurance/quality control measure.

All of the mill and board-line process samples collected were analyzed for mercury content, by cold vapor atomic absorption after digestion in hydrofluoric acid. A number of samples were analyzed for other parameters, including gypsum moisture content, particle size distribution, specific surface area, and chloride content.

The mercury concentration analytical results, along with plant process data, were used to construct a mercury balance across the mill and the board line. The mercury balances show individual stream flow rates and mercury concentrations (except for the additives used in the board line), the amount of mercury entering and leaving the plant in each process stream, and overall mercury mass balance closures. Data are shown for individual sampling runs and as means for the triplicate measurements.

Coal data, power plant data, and FGD process data from the power plant producing the synthetic gypsum evaluated are currently being collected and tabulated. These data will be reported later in the project. 


\section{RESULTS AND DISCUSSION}

This section provides technical results for the Task 5 wallboard plant test. Results presented include gypsum and process sample analysis results, Ontario Hydro flue gas measurement results, plant process data, and mercury balance results. Each type of result is discussed in a separate subsection below.

\section{Gypsum and Process Sample Mercury Analysis Results}

Table 3 summarizes the results of mercury and moisture content analyses conducted by URS on the raw gypsum, stucco product, and intermediate process samples collected during the mill test on March 21, 2006. Table 4 shows results for additional characterization of these samples conducted by USG, including mercury, free and combined (water of hydration only) moisture content as well as other parameters. Table 5 shows the results for mercury and moisture content analyses conducted by URS on stucco, wallboard product, and intermediate process samples collected during the board-line test on March 22, 2006, and Table 6 shows corresponding USG analysis results.

Table 3. Task 5 Raw Gypsum and Mill Process Sample Mercury and Moisture Analyses, URS Results

\begin{tabular}{|c|c|c|c|c|c|c|c|c|c|c|}
\hline \multirow[b]{2}{*}{$\begin{array}{l}\text { Sample } \\
\text { Number }\end{array}$} & \multirow[b]{2}{*}{ Sample Description } & \multicolumn{5}{|c|}{ Mercury Content, $\mu \mathrm{g} / \mathrm{g}$ (dry basis) } & \multicolumn{4}{|c|}{$\begin{array}{l}\text { Moisture Content, wt } \% \text { as } \\
\text { received }\end{array}$} \\
\hline & & $\begin{array}{l}\text { Run } \\
1\end{array}$ & $\begin{array}{l}\text { Run } \\
2\end{array}$ & $\begin{array}{l}\text { Run } \\
3\end{array}$ & Mean & $\begin{array}{l}95 \% \\
\text { C.I.* }\end{array}$ & $\begin{array}{l}\text { Run } \\
1\end{array}$ & $\begin{array}{l}\text { Run } \\
2\end{array}$ & $\begin{array}{l}\text { Run } \\
3\end{array}$ & Mean \\
\hline S1 & $\begin{array}{l}\text { Raw Gypsum Feed to } \\
\text { Dryer Mill }\end{array}$ & 0.17 & 0.21 & 0.23 & 0.20 & 0.04 & 11.4 & 10.9 & 10.4 & 10.9 \\
\hline S2 & $\begin{array}{l}\text { Land Plaster from } \\
\text { Dryer Mill }\end{array}$ & 0.14 & 0.19 & 0.20 & 0.18 & 0.04 & 0.1 & 0.1 & 0.1 & 0.1 \\
\hline S3 & $\begin{array}{l}\text { Land Plaster to Kettle } \\
\text { Calciner }\end{array}$ & 0.15 & 0.20 & 0.20 & 0.18 & 0.03 & 0.1 & 0.1 & 0.1 & 0.1 \\
\hline \multirow[t]{2}{*}{ S5 } & $\begin{array}{l}\text { Kettle Calciner } \\
\text { Product, as } \\
\text { measured }\end{array}$ & 0.11 & 0.12 & 0.14 & 0.12 & 0.02 & 0.0 & 0.0 & 0.0 & 0.0 \\
\hline & $\begin{array}{l}\text { Kettle Calciner } \\
\text { Product, dry gypsum } \\
\text { basis }\end{array}$ & 0.09 & 0.10 & 0.12 & 0.10 & 0.01 & - & - & - & - \\
\hline \multirow[t]{2}{*}{ S6 } & $\begin{array}{l}\text { Kettle Calciner Dust } \\
\text { Collector Solids, as } \\
\text { measured }\end{array}$ & 0.14 & 0.19 & 0.21 & 0.18 & 0.04 & 0.4 & 0.1 & 0.1 & 0.2 \\
\hline & $\begin{array}{l}\text { Kettle Calciner Dust } \\
\text { Collector Solids, dry } \\
\text { gypsum basis }\end{array}$ & 0.12 & 0.16 & 0.18 & 0.15 & 0.04 & - & - & - & - \\
\hline \multirow[t]{2}{*}{ S7 } & $\begin{array}{l}\text { Product Stucco, as } \\
\text { measured }\end{array}$ & 0.13 & 0.15 & 0.18 & 0.15 & 0.03 & 0.0 & 0.0 & 0.0 & 0.0 \\
\hline & $\begin{array}{l}\text { Product Stucco, dry } \\
\text { gypsum basis }\end{array}$ & 0.11 & 0.13 & 0.15 & 0.13 & 0.03 & - & - & - & - \\
\hline
\end{tabular}

*95\% Confidence Interval of mean 
Table 4. Task 5 Mill Line Process Sample Characterization, USG Results

\begin{tabular}{|c|c|c|c|c|c|c|c|c|c|c|c|c|}
\hline \multirow[b]{3}{*}{ Sample } & \multirow[b]{3}{*}{ Run } & \multicolumn{2}{|c|}{$\begin{array}{l}\text { Moisture } \\
\text { Content, } \\
\text { wt\% }\end{array}$} & \multicolumn{2}{|c|}{$\begin{array}{l}\text { Mercury Content, } \\
\mu \mathrm{g} / \mathrm{g}\end{array}$} & \multicolumn{2}{|c|}{$\begin{array}{l}\text { Soluble } \\
\text { Salts, ppm }\end{array}$} & \multicolumn{4}{|c|}{$\begin{array}{l}\text { Particle Size Distribution } \\
\text { (microns) }\end{array}$} & \multirow[t]{3}{*}{$\begin{array}{l}\text { Blaine } \\
\text { Surface } \\
\text { Area, } \\
\mathrm{cm}^{2} / \mathrm{gm}\end{array}$} \\
\hline & & \multirow[b]{2}{*}{ Free } & \multirow{2}{*}{$\begin{array}{l}\text { Com- } \\
\text { bined } \\
\star\end{array}$} & \multirow{2}{*}{$\begin{array}{l}\text { As } \\
\text { measured, } \\
\text { dry basis }\end{array}$} & \multirow{2}{*}{$\begin{array}{l}\text { Dry } \\
\text { Gypsum } \\
\text { basis }\end{array}$} & \multirow[b]{2}{*}{ Total } & \multirow[b]{2}{*}{$\mathrm{Cl}^{-}$} & \multirow{2}{*}{$\begin{array}{l}\text { Mean } \\
\text { Dia. }\end{array}$} & \multicolumn{3}{|c|}{$\begin{array}{c}\text { Particle Size at \% } \\
\text { Less Than }\end{array}$} & \\
\hline & & & & & & & & & $10 \%$ & $50 \%$ & $95 \%$ & \\
\hline \multirow{3}{*}{$\begin{array}{l}\text { S1 - Raw } \\
\text { Gypsum Feed } \\
\text { to Dryer Mill }\end{array}$} & 1 & NA & 19.9 & 0.13 & 0.12 & 105 & 30 & 47.9 & 24.8 & 44.8 & 86.7 & 905 \\
\hline & 2 & NA & 20.0 & 0.16 & 0.16 & 97 & 23 & 49.3 & 26.8 & 46.1 & 87.7 & 866 \\
\hline & 3 & NA & 20.0 & 0.16 & 0.16 & 174 & 18 & 51.0 & 27.9 & 47.3 & 91.4 & 846 \\
\hline \multicolumn{2}{|l|}{ Mean } & NA & 19.9 & 0.15 & 0.15 & 125 & 24 & 49.4 & 26.5 & 46.1 & 88.6 & 872 \\
\hline \multicolumn{2}{|l|}{ 95\% C.I. ${ }^{*}$} & NA & \pm 0.1 & \pm 0.02 & \pm 0.02 & \pm 48 & \pm 7 & \pm 1.8 & \pm 1.8 & \pm 1.4 & \pm 2.8 & \pm 34 \\
\hline \multirow{3}{*}{$\begin{array}{l}\text { S2 - Land } \\
\text { Plaster from } \\
\text { Dryer Mill }\end{array}$} & 1 & 0.08 & 19.5 & 0.15 & 0.15 & 116 & 32 & 43.5 & 21.8 & 42.2 & 74.8 & 1053 \\
\hline & 2 & 0.07 & 18.9 & 0.19 & 0.19 & 87 & 25 & 48.9 & 24.9 & 45.4 & 89.9 & 965 \\
\hline & 3 & 0.04 & 19.5 & 0.21 & 0.21 & 227 & 36 & 48.3 & 24.2 & 44.9 & 88.9 & 956 \\
\hline \multicolumn{2}{|l|}{ Mean } & 0.06 & 19.3 & 0.18 & 0.18 & 143 & 31 & 46.9 & 23.6 & 44.2 & 84.5 & 991 \\
\hline \multicolumn{2}{|l|}{ 95\% C.I. } & \pm 0.02 & \pm 0.4 & \pm 0.04 & \pm 0.04 & \pm 84 & \pm 6 & \pm 3.4 & \pm 1.8 & \pm 1.9 & \pm 9.5 & \pm 61 \\
\hline \multirow{3}{*}{$\begin{array}{l}\text { S3 - Land } \\
\text { Plaster to Kettle } \\
\text { Calciner }\end{array}$} & 1 & 0.06 & 19.0 & 0.14 & 0.14 & 107 & 31 & 47.9 & 24.4 & 44.6 & 88.0 & 1053 \\
\hline & 2 & 0.14 & 19.1 & 0.18 & 0.17 & 103 & 28 & 48.9 & 25.0 & 45.5 & 89.3 & 1070 \\
\hline & 3 & 0.06 & 19.5 & 0.19 & 0.19 & 185 & 23 & 49.5 & 25.5 & 45.9 & 90.4 & 1001 \\
\hline \multicolumn{2}{|l|}{ Mean } & 0.09 & 19.2 & 0.17 & 0.17 & 132 & 27 & 48.8 & 25.0 & 45.3 & 89.2 & 1041 \\
\hline \multicolumn{2}{|l|}{ 95\% C.I. } & \pm 0.05 & \pm 0.3 & \pm 0.03 & \pm 0.03 & \pm 52 & \pm 5 & \pm 0.9 & \pm 0.6 & \pm 0.8 & \pm 1.3 & \pm 41 \\
\hline \multirow{3}{*}{$\begin{array}{l}\text { S5-Kettle } \\
\text { Calciner } \\
\text { Product }\end{array}$} & 1 & 0 & 6.3 & 0.10 & 0.09 & 110 & 47 & 52.6 & 29.4 & 48.3 & 94.6 & 1466 \\
\hline & 2 & 0 & 6.4 & 0.12 & 0.11 & 98 & 49 & 52.8 & 30.0 & 48.6 & 93.8 & 1446 \\
\hline & 3 & 0 & 6.4 & 0.13 & 0.11 & 193 & 44 & 52.5 & 29.6 & 48.1 & 94.3 & 1483 \\
\hline \multicolumn{2}{|l|}{ Mean } & 0.00 & 6.4 & 0.12 & 0.10 & 133 & 47 & 52.6 & 29.7 & 48.4 & 94.2 & 1465 \\
\hline 95\% C.I. & & \pm 0.00 & \pm 0.1 & \pm 0.01 & \pm 0.01 & \pm 58 & \pm 3 & \pm 0.2 & \pm 0.3 & \pm 0.3 & \pm 0.5 & \pm 21 \\
\hline S6-Kettle & 1 & 0.14 & 6.9 & 0.16 & 0.14 & 101 & 44 & 40.2 & 17.3 & 37.9 & 76.3 & 2099 \\
\hline Calciner Dust & 2 & 0.23 & 6.7 & 0.19 & 0.17 & 98 & 44 & 40.1 & 16.6 & 37.8 & 76.7 & 1943 \\
\hline Collector & 3 & 0.16 & 7.0 & 0.24 & 0.21 & 252 & 61 & 38.1 & 15.5 & 35.7 & 73.5 & 2203 \\
\hline Mean & & 0.18 & 6.9 & 0.20 & 0.17 & 151 & 50 & 39.5 & 16.4 & 37.1 & 75.5 & 2082 \\
\hline 95\% C.I. & & \pm 0.05 & \pm 0.2 & \pm 0.05 & \pm 0.04 & \pm 100 & \pm 11 & \pm 1.4 & \pm 1.0 & \pm 1.4 & \pm 2.0 & \pm 148 \\
\hline S7 - Stucco to & 1 & 0.03 & 6.7 & 0.13 & 0.11 & 121 & 48 & 40.0 & 19.9 & 37.1 & 73.6 & 1929 \\
\hline Product Bin & 2 & 0.29 & 6.8 & 0.15 & 0.13 & 144 & 56 & 38.5 & 18.4 & 35.5 & 72.2 & 1981 \\
\hline & 3 & 0.29 & 6.7 & 0.17 & 0.15 & 243 & 46 & 37.6 & 18.0 & 34.6 & 70.6 & 2087 \\
\hline Mean & & 0.20 & 6.7 & 0.15 & 0.13 & 169 & 50 & 38.7 & 18.8 & 35.8 & 72.1 & 1999 \\
\hline 95\% C.I. & & \pm 0.17 & \pm 0.1 & \pm 0.03 & \pm 0.02 & \pm 73 & \pm 6 & \pm 1.4 & \pm 1.1 & \pm 1.5 & \pm 1.7 & \pm 91 \\
\hline
\end{tabular}

NA - not analyzed

*Values shown represent waters of hydration only - do not include free moisture content 
Table 5. Task 5 Board-line Process Sample Analyses, URS Results

\begin{tabular}{|c|c|c|c|c|c|c|c|c|c|c|}
\hline \multirow[b]{2}{*}{$\begin{array}{l}\text { Sample } \\
\text { Number }\end{array}$} & \multirow[b]{2}{*}{$\begin{array}{l}\text { Sample } \\
\text { Description }\end{array}$} & \multicolumn{5}{|c|}{ Mercury Content, $\mu \mathrm{g} / \mathrm{g}$ (dry basis) } & \multicolumn{4}{|c|}{$\begin{array}{l}\text { Free Moisture Content, wt\% } \\
\text { as received }\end{array}$} \\
\hline & & $\begin{array}{l}\text { Run } \\
1\end{array}$ & $\begin{array}{l}\text { Run } \\
2^{*}\end{array}$ & $\begin{array}{l}\text { Run } \\
3\end{array}$ & Mean & $\begin{array}{l}95 \% \\
\text { C.I. }\end{array}$ & $\begin{array}{l}\text { Run } \\
1\end{array}$ & $\begin{array}{l}\text { Run } \\
2^{*}\end{array}$ & $\begin{array}{l}\text { Run } \\
3\end{array}$ & Mean \\
\hline \multirow[t]{2}{*}{ S8 } & $\begin{array}{l}\text { Stucco Feed, as } \\
\text { measured }\end{array}$ & 0.15 & 0.14 & 0.14 & 0.14 & \pm 0.01 & 0.0 & 0.0 & 0.0 & 0.0 \\
\hline & $\begin{array}{l}\text { Stucco Feed, dry } \\
\text { gypsum basis }\end{array}$ & 0.13 & 0.11 & 0.12 & 0.12 & \pm 0.01 & - & - & - & - \\
\hline S9 & $\begin{array}{l}\text { Slurry to } \\
\text { Forming Rolls }\end{array}$ & 0.13 & 0.11 & 0.09 & 0.11 & \pm 0.02 & $22.1^{\star \star}$ & $28.7^{* \star}$ & $30.2^{\star \star}$ & $27.0^{\star \star}$ \\
\hline S10 & Wet Wallboard & 0.13 & 0.11 & 0.10 & 0.11 & \pm 0.01 & $24.7^{\star \star}$ & $26.3^{\star \star}$ & $29.6^{\star \star}$ & $26.8^{\star \star}$ \\
\hline S11 & Dry Wallboard & 0.14 & 0.12 & 0.11 & 0.12 & \pm 0.01 & 0.9 & 0.6 & 1.0 & 0.8 \\
\hline
\end{tabular}

* Mean value for two samples, one from beginning and one from end of run

**Moisture content measured after sample set up, consuming some free moisture to rehydrate the stucco

Table 6. Task 5 Board Line Process Sample Characterization, USG Results

\begin{tabular}{|c|c|c|c|c|c|c|c|c|c|c|c|c|}
\hline \multirow[b]{3}{*}{ Sample } & \multirow[b]{3}{*}{ Run } & \multicolumn{2}{|c|}{$\begin{array}{l}\text { Moisture } \\
\text { Content, } \\
\text { wt\% }\end{array}$} & \multicolumn{2}{|c|}{$\begin{array}{l}\text { Mercury Content, } \\
\mu \mathrm{g} / \mathrm{g}\end{array}$} & \multicolumn{2}{|c|}{$\begin{array}{l}\text { Soluble } \\
\text { Salts, ppm }\end{array}$} & \multicolumn{4}{|c|}{$\begin{array}{l}\text { Particle Size Distribution } \\
\text { (microns) }\end{array}$} & \multirow[t]{3}{*}{$\begin{array}{l}\text { Blaine } \\
\text { Surface } \\
\text { Area, } \\
\mathrm{Cm}^{2} / \mathrm{gm}\end{array}$} \\
\hline & & \multirow[b]{2}{*}{ Free } & \multirow{2}{*}{$\begin{array}{l}\text { Com- } \\
\text { bined } \\
\text { * }\end{array}$} & \multirow{2}{*}{$\begin{array}{l}\text { As } \\
\text { measured, } \\
\text { dry basis }\end{array}$} & \multirow{2}{*}{\begin{tabular}{|l} 
Dry \\
Gypsum \\
basis \\
\end{tabular}} & \multirow[b]{2}{*}{ Total } & \multirow[b]{2}{*}{$\mathrm{Cl}^{-}$} & \multirow{2}{*}{$\begin{array}{l}\text { Mean } \\
\text { Dia. }\end{array}$} & \multicolumn{3}{|c|}{\begin{tabular}{|c|}
$\begin{array}{c}\text { Particle Size at \% } \\
\text { Less Than }\end{array}$ \\
\end{tabular}} & \\
\hline & & & & & & & & & $10 \%$ & $50 \%$ & $95 \%$ & \\
\hline \multirow{3}{*}{\begin{tabular}{|l|} 
S8 - Stucco \\
Feed to Board \\
Line
\end{tabular}} & 1 & 0.01 & 6.7 & 0.15 & 0.13 & 117 & 45 & 40.9 & 10.1 & 39.2 & 83.2 & 2729 \\
\hline & $2^{\star \star}$ & 0.05 & 6.5 & 0.13 & 0.11 & 118 & 40 & 41.9 & 9.7 & 39.4 & 86.5 & 2803 \\
\hline & 3 & 0.01 & 6.6 & 0.13 & 0.11 & 244 & 41 & 41.1 & 10.5 & 39.4 & 82.9 & 2665 \\
\hline \multicolumn{2}{|l|}{ Mean } & 0.02 & 6.5 & 0.13 & 0.11 & 149 & 40 & 41.7 & 9.9 & 39.4 & 85.6 & 2769 \\
\hline \multicolumn{2}{|l|}{ 95\% C.I. } & \pm 0.03 & \pm 0.1 & \pm 0.01 & \pm 0.01 & \pm 83 & \pm 3 & \pm 0.7 & \pm 0.5 & \pm 0.1 & \pm 2.2 & \pm 78 \\
\hline \multirow{3}{*}{$\begin{array}{l}\text { S9 - Slurry } \\
\text { Feed }\end{array}$} & 1 & NA & 20.1 & 0.13 & 0.13 & - & - & - & - & - & - & - \\
\hline & $2^{\star \star}$ & NA & 19.9 & 0.11 & 0.11 & - & - & - & - & - & - & - \\
\hline & 3 & NA & 19.9 & 0.11 & 0.11 & - & - & - & - & - & - & - \\
\hline \multicolumn{2}{|l|}{ Mean } & NA & 20.0 & 0.12 & 0.12 & - & - & - & - & - & - & - \\
\hline \multicolumn{2}{|l|}{$95 \%$ C.I. } & NA & \pm 0.2 & \pm 0.01 & \pm 0.01 & - & - & - & - & - & - & - \\
\hline \multirow{3}{*}{$\begin{array}{l}\text { S10 - Wet } \\
\text { Wallboard }\end{array}$} & 1 & 22.3 & 19.9 & 0.13 & 0.13 & - & - & - & - & - & - & - \\
\hline & $2^{\star \star}$ & 23.5 & 19.9 & 0.11 & 0.11 & - & - & - & - & - & - & - \\
\hline & 3 & 25.6 & 20.0 & 0.11 & 0.11 & - & - & - & - & - & - & - \\
\hline \multicolumn{2}{|l|}{ Mean } & 23.8 & 19.9 & 0.12 & 0.12 & - & - & - & - & - & - & - \\
\hline \multicolumn{2}{|l|}{ 95\% C.I. } & \pm 1.9 & \pm 0.0 & \pm 0.01 & \pm 0.01 & - & - & - & - & - & - & - \\
\hline \multirow{3}{*}{$\begin{array}{l}\text { S11 - Dry } \\
\text { Product } \\
\text { Wallboard }\end{array}$} & 1 & 0.15 & 18.9 & 0.13 & 0.13 & - & - & - & - & - & - & - \\
\hline & $2^{* \star}$ & 0.15 & 18.6 & 0.12 & 0.12 & - & - & - & - & - & - & - \\
\hline & 3 & 0.13 & 18.8 & 0.12 & 0.12 & - & - & - & - & - & - & - \\
\hline \multicolumn{2}{|l|}{ Mean } & 0.14 & 18.8 & 0.12 & 0.12 & - & - & - & - & - & - & - \\
\hline \multicolumn{2}{|l|}{ 95\% C.I. } & \pm 0.01 & \pm 0.2 & \pm 0.01 & \pm 0.01 & - & - & - & - & - & - & - \\
\hline
\end{tabular}

NA - not analyzed

*Values shown represent waters of hydration only - do not include free moisture content

** Mean value for two samples, one from beginning and one from end of run 
As in previous Topical Reports produced as part of this project, a mean and a 95\% confidence interval about that mean have been shown for key values in the tables. The mean values represent the arithmetic average of the results from three runs, while the 95\% confidence interval is a measure of observed variability of that value during the three runs.

The results from the URS analyses in Table 3 show that for the three dryer mill tests, the raw gypsum feed contained an average of $0.20 \mu \mathrm{g} / \mathrm{g}$ (dry basis) and 11\% moisture, the latter of which is in the typical range for FGD gypsum. The gypsum mercury content varied through the day, though, starting at $0.17 \mu \mathrm{g} / \mathrm{g}$ in the sample from the first run and increasing to $0.23 \mu \mathrm{g} / \mathrm{g}$ for the sample from the third run. Note that the mercury concentration in the gypsum from Power Plant $\mathrm{E}$ is about one-fifth of that from Power Plant A (tested in Tasks 1 and 2), similar to that from Power Plant B (tested in Task 3), and less than half that from Power Plant C (Task 4).

Notwithstanding potential mercury losses in the kettle calciner, mercury should be more concentrated in the kettle calciner product and in the product stucco than in the upstream samples, because of the evolution of $1 \frac{1}{2}$ waters of hydration in the calciner. For this reason, additional rows of data are shown in Table 3 expressing the mercury content in the stucco samples (S5, S6, and S7) on a dry gypsum basis. This accounts for the effects of the loss of waters of hydration by the stucco. Similarly, a column in Table 4 shows all of the solids analysis results on a dry gypsum basis.

The corrected values can be compared directly to see apparent mercury losses across the dryer mill and kettle calciner. About 10\% loss of mercury is indicated across the dryer mill based on the average mercury concentration in the land plaster compared to the average mercury concentration in the raw gypsum feed. However, because the gypsum mercury content was somewhat variable through the day, comparison of process "grab" samples for mercury content may not be the most reliable method of quantifying mercury losses.

When comparing the mercury concentrations in the land plaster feed to the kettle calciner (S3) to the mercury concentrations in the product stucco (S7) expressed on a dry gypsum basis, significant losses of mercury are apparent across the kettle calciner. The feed gypsum averaged $0.18 \mu \mathrm{g} / \mathrm{g}$ of mercury content on a dry basis (dry of free moisture only - not waters of hydration) while the product stucco averaged $0.13 \mu \mathrm{g} / \mathrm{g}$ when expressed on a dry gypsum basis, about 30\% loss. However, as mentioned above, given that these values reflect only single sets of grab samples per run, and that the mercury concentrations were changing throughout the day, there is uncertainty in quantifying mercury losses by comparing mercury analyses on these samples. The Ontario Hydro stack sampling results for the kettle calciner are thought to provide a better measure of this loss percentage.

The results of USG analyses in Table 4 show mercury concentrations that are very similar to those measured by URS on splits of the same samples. Perhaps the most important samples for this test are S3, the kettle calciner feed, and S7, the product stucco, as those provide an indication of any mercury losses across the kettle calciner. For sample S3, the URS analyses showed a mean concentration of $0.18 \mu \mathrm{g} / \mathrm{g}$, while the USG analyses showed a mean of $0.17 \mu \mathrm{g} / \mathrm{g}$. For sample S7, the URS analyses showed a mean concentration of $0.15 \mu \mathrm{g} / \mathrm{g}$ (as measured), while 
the USG analyses showed an identical mean of $0.15 \mu \mathrm{g} / \mathrm{g}$. This is considered excellent agreement between two laboratories analyzing separate splits of the same sample by different methods.

The USG characterization of these samples generally shows expected trends. For example, the specific surface area of the land plaster is observed to increase from about $1,000 \mathrm{~cm}^{2} / \mathrm{g}$ into the range of 1,500 to greater than $2,000 \mathrm{~cm}^{2} / \mathrm{g}$ upon calcining, which would be expected due to the evolution of waters of hydration from the particles. One interesting result is a comparison of the combined moisture content (water of hydration content) of the samples collected downstream of the calciner (S5 through S7). A sample of 100\% pure gypsum should have a combined moisture content of $20.9 \mathrm{wt} \%$, while $100 \%$ stucco should have a combined moisture content of $6.2 \mathrm{wt} \%$. The average value of $6.4 \mathrm{wt} \%$ in the kettle calciner overflow product is indicative of near 100\% calcining efficiency. However, the dust collector solids (S6) were measured to have a higher combined moisture content of $6.9 \%$. This may be an indication that the fine particles collected in the dust collector are entrained out of the kettle calciner more rapidly and are not calcined as efficiently, or perhaps that the dust collector solids partially rehydrate on the dust collector bags while contacting humid flue gas. The stucco to the product bin (S7), which is a mixture of these two streams, had an intermediate combined moisture content, as would be expected.

The results from the board line samples in Table 5 show that the mercury concentrations in the stucco feed to the wallboard plant (S8) were close to the values measured in the product stucco going to the stucco storage bin (S7). S7 averaged $0.14 \mu \mathrm{g} / \mathrm{g}$ of mercury content, while S8 samples from the day before averaged $0.15 \mu \mathrm{g} / \mathrm{g}$. The S8 feed stucco sample mercury content was measured to be more consistent than the previous day's S7 mill product stucco samples, with a standard deviation of only 0.01 compared to $0.03 \mu \mathrm{g} / \mathrm{g}$ for the S7 samples. This suggests that some blending occurred in the stucco product bins that tended to minimize mercury concentration variations.

Conversely to what was described above for the kettle calciner, in the board line the slurry and wallboard should have lower mercury concentrations than the feed stucco, due to the $1 \frac{1}{2}$ waters of hydration gained on rehydration of the stucco. To account for this effect, a row has been added to Table 5 showing the feed stucco mercury concentration on a dry gypsum basis, and a corresponding column has been added to Table 6. This allows any loss of mercury from the feed stucco to be observed directly by comparing mercury concentrations of the feed and product on a common dry gypsum basis. These results give no indication of mercury loss across the board line, as the product wallboard was measured to have a slightly higher mercury content than the stucco feed when express on a dry gypsum basis (an average value of $0.12 \mu \mathrm{g} / \mathrm{g}$ versus $0.11 \mu \mathrm{g} / \mathrm{g}$ for the stucco). However, the effects of mercury in the additives, water, and paper added in the board line on the mercury content of the wallboard product must also be considered, as discussed later in this section with the mercury mass balance results.

As for the mill samples, a comparison of the results of USG analyses of board-line samples for mercury content, summarized in Table 6, agree well with the URS results. For example, on an as-measured basis, the stucco feed (S8) mercury concentration was measured at an average of $0.14 \mu \mathrm{g} / \mathrm{g}$ by URS and $0.13 \mu \mathrm{g} / \mathrm{g}$ by USG. The wallboard product mercury content was measured as $0.12 \mu \mathrm{g} / \mathrm{g}$ by both URS and USG. 


\section{Ontario Hydro Stack Sampling Results}

The Ontario Hydro method stack sampling results are summarized in tables that follow. Table 7 summarizes gas flow rate, temperature, and major component concentrations. The results in the table show that the mill dryer stream composition was consistent with a dilute flue gas from natural gas firing, with about $1 \% \mathrm{CO}_{2}$ and $19 \%$ oxygen. The moisture content was relatively high at about $12 \%$, due to the free moisture from the gypsum that is evolved in the dryer. The dryer mill flue gas temperature was well below $200^{\circ} \mathrm{F}$, as would be expected because of the need to keep the dried gypsum below its initial calcination temperature of $262^{\circ} \mathrm{F}$.

Table 7. Task 5 Ontario Hydro Results - Summary of Exhaust Gas Conditions

\begin{tabular}{|c|c|c|c|c|c|c|c|c|c|}
\hline \multirow{2}{*}{$\begin{array}{l}\text { Sample } \\
\text { Number }\end{array}$} & \multirow[b]{2}{*}{ Run No. } & \multirow{2}{*}{$\begin{array}{l}\text { Date } \\
(2006)\end{array}$} & \multirow{2}{*}{$\begin{array}{l}\text { Time } \\
\text { (24-h) }\end{array}$} & \multicolumn{2}{|c|}{ Flow Rate } & \multirow{2}{*}{$\begin{array}{c}\text { Temperature } \\
\left({ }^{\circ} \mathrm{F}\right)\end{array}$} & \multirow{2}{*}{$\begin{array}{l}\mathrm{H}_{2} \mathrm{O} \\
(\%)\end{array}$} & \multirow{2}{*}{$\begin{array}{l}\mathrm{CO}_{2} \\
(\%)\end{array}$} & \multirow{2}{*}{$\begin{array}{c}\mathrm{O}_{2} \\
(\%)\end{array}$} \\
\hline & & & & acfm* & Dscfm $^{\#}$ & & & & \\
\hline \multicolumn{10}{|c|}{ Dryer Mill (1 of 1$)$} \\
\hline \multirow[t]{4}{*}{$\mathrm{S} 12$} & 1 & $3 / 21$ & $\begin{array}{c}1008- \\
1216\end{array}$ & 26,400 & 18,600 & 172 & 12.9 & 1.1 & 18.9 \\
\hline & 2 & $3 / 21$ & $\begin{array}{c}1329- \\
1536 \\
\end{array}$ & 27,700 & 19,800 & 172 & 11.2 & 0.9 & 19.3 \\
\hline & 3 & $3 / 21$ & $\begin{array}{c}1609- \\
1817 \\
\end{array}$ & 27,400 & 19,800 & 167 & 10.9 & 1.0 & 19.2 \\
\hline & Mean & & & 27,200 & 19,400 & 170 & 11.7 & 1.0 & 19.1 \\
\hline \multicolumn{10}{|c|}{ Kettle Calciner ( 1 of 2 operating) } \\
\hline \multirow[t]{4}{*}{ S13 } & 1 & $3 / 21$ & $\begin{array}{c}1118- \\
1234 \\
\end{array}$ & 5,540 & 2,200 & 248 & 47.3 & 0.2 & 20.7 \\
\hline & 2 & $3 / 21$ & $\begin{array}{c}1355- \\
1508 \\
\end{array}$ & 5,510 & 2,120 & 250 & 48.4 & 0.2 & 20.6 \\
\hline & 3 & $3 / 21$ & $\begin{array}{c}1638- \\
1744 \\
\end{array}$ & 5,560 & 2,160 & 252 & 50.1 & 0.2 & 20.8 \\
\hline & Mean & & & 5,530 & 2,130 & 250 & 48.6 & 0.2 & 20.7 \\
\hline \multicolumn{10}{|c|}{ Board Dryer Kiln (1 of 1 ) } \\
\hline \multirow{4}{*}{$\begin{array}{l}\text { S14a } \\
\text { (wet } \\
\text { end) }\end{array}$} & 1 & $3 / 22$ & $\begin{array}{c}0904- \\
1110 \\
\end{array}$ & 24,600 & 14,200 & 282 & 20.9 & 0.9 & 19.3 \\
\hline & 2 & $3 / 22$ & $\begin{array}{c}1220- \\
1426 \\
\end{array}$ & 29,300 & 16,300 & 268 & 25.3 & 2.0 & 17.2 \\
\hline & 3 & $3 / 22$ & $\begin{array}{c}1501- \\
1707 \\
\end{array}$ & 28,500 & 15,300 & 257 & 27.9 & 2.3 & 16.7 \\
\hline & Mean & & & 27,500 & 15,300 & 269 & 24.7 & 1.7 & 17.7 \\
\hline \multirow{4}{*}{$\begin{array}{l}\text { S14b } \\
\text { (dry } \\
\text { end) }\end{array}$} & 1 & $3 / 22$ & $\begin{array}{c}0904- \\
1109 \\
\end{array}$ & 29,700 & 22,700 & 201 & 6.4 & 0.8 & 19.4 \\
\hline & 2 & $3 / 22$ & $\begin{array}{c}1219- \\
1423 \\
\end{array}$ & 30,100 & 22,800 & 194 & 8.5 & 0.8 & 19.4 \\
\hline & 3 & $3 / 22$ & $\begin{array}{c}1502- \\
1705 \\
\end{array}$ & 31,000 & 22,800 & 189 & 10.1 & 0.9 & 19.3 \\
\hline & Mean & & & 30,200 & 22,700 & 195 & 8.4 & 0.8 & 19.4 \\
\hline
\end{tabular}


*acfm = Actual cubic feet per minute at stack conditions

**dscfm = Dry standard cubic feet per minute; standard conditions are $68^{\circ} \mathrm{F}, 29.92 \mathrm{in} . \mathrm{Hg}$, and 0 percent moisture

The kettle calciner results for flue gas composition were consistent with a very wet air stream, containing a trace $\mathrm{CO}_{2}$ content of $0.2 \%$ and nearly $21 \%$ oxygen. The measured moisture content of the stack gas was high, averaging $49 \%$ due to the waters of hydration released from the gypsum. The measured moisture content was slightly lower than what was measured at Wallboard Plant 1 in Tasks 1 and 2 and Wallboard Plant 3 in Task 4 ( 55\%), and considerably lower than was measured at Wallboard Plant 2 in Task 3 (79\%).

The board dryer kiln sampling results showed that the "wet end" stack flue gas flow rate is slightly lower than the "dry end" flue gas rate. It is also hotter, slightly more concentrated (lower measured oxygen concentration), and wetter. The higher temperature and higher moisture content would be expected at the wet end.

Table 8 summarizes the mercury concentration and mass rate data. The results show that for the dryer mill and kettle calciner stacks, the mercury is mostly in the elemental form $\left(\mathrm{Hg}^{0}\right)$. This was generally seen at the wallboard plants previously tested in Tasks 1 through 4. This phenomenon remains somewhat surprising, given that it is predominantly water-soluble oxidized mercury $\left(\mathrm{Hg}^{+2}\right)$ that is removed in wet FGD systems, while elemental mercury is virtually insoluble and not removed at significant percentages. There still is no clear explanation for this phenomenon. One possibility is that a portion of the oxidized mercury absorbed in the FGD system undergoes reactions after the mercury is deposited in the byproduct solids to reduce a portion of the oxidized mercury to the elemental form. Alternatively, an unknown mechanism for the absorption of a small percentage of elemental mercury in the FGD system could provide another explanation as to the presence of the elemental mercury in the stack emissions. Note that in the elemental form, mercury is not expected to readily deposit near the point of emission but ascends into the atmosphere and contributes to the overall global cycle. ${ }^{6}$

For the board dryer kiln, the results showed mostly elemental mercury in the wet end stack but closer to equal percentages of oxidized and elemental mercury in the dry end stack flue gas. However, in the dry end stack flue gas the measured concentrations were extremely low; with two of the total mercury concentration measurements at or below the stated detection limit of the Ontario Hydro method of $0.5 \mu \mathrm{g} / \mathrm{Nm}^{3}$, so the observed mercury speciation data may not be meaningful. ${ }^{7}$

The total mercury concentration data show that on a dry gas basis, the concentrations in the kettle calciner steam stack were approximately $270 \mu \mathrm{g} / \mathrm{Nm}^{3}$, while the dryer mill stack averaged $2 \mu \mathrm{g} / \mathrm{Nm}^{3}$. The measured total mercury concentrations in the board dryer kiln stacks were low, with a mean value between 1 and $2 \mu \mathrm{g} / \mathrm{Nm}^{3}$ in the wet end stack and less than $0.5 \mu \mathrm{g} / \mathrm{Nm}^{3}$ in the dry end stack.

Compared to the total mercury concentrations measured in the previous wallboard plant tests, the mercury concentrations measured in the dryer mill stack at Wallboard Plant 4 were in the middle of the range (a mean value of $2 \mu \mathrm{g} / \mathrm{Nm}^{3}$ compared to a range of $<0.5 \mu \mathrm{g} / \mathrm{Nm}^{3}$ to $7 \mu \mathrm{g} / \mathrm{Nm}^{3}$ ). For the kettle calciner stack, the concentrations measured were $60 \%$ to $100 \%$ higher than were measured at Wallboard Plant 1 as part of Tasks 1 and 2, about 14 times higher than were 
measured at Wallboard Plant 3 as part of Task 4, but a factor of 7 lower than were measured at Wallboard Plant 2 as part of Task 3.

Table 8. Task 5 Ontario Hydro Results - Speciated Mercury Emissions Data

\begin{tabular}{|c|c|c|c|c|c|c|c|c|}
\hline \multirow[b]{2}{*}{$\begin{array}{l}\text { Sample } \\
\text { Number }\end{array}$} & \multirow[b]{2}{*}{$\begin{array}{l}\text { Run } \\
\text { No. }\end{array}$} & \multirow[b]{2}{*}{$\begin{array}{c}\text { Date } \\
(2005)\end{array}$} & \multirow[b]{2}{*}{$\begin{array}{l}\text { Time } \\
(24-h)\end{array}$} & \multicolumn{4}{|c|}{ Concentration $\left(\mu \mathrm{g} / \mathrm{Nm}^{3}\right)^{*}$} & \multirow{2}{*}{$\begin{array}{c}\text { Total } \\
\text { Mercury } \\
\text { Emissior } \\
\text { Rate } \\
\text { (lb/h) }\end{array}$} \\
\hline & & & & $\begin{array}{c}\text { Particle- } \\
\text { Bound, } \\
\text { Hg }^{\mathrm{P}}\end{array}$ & $\underset{\mathbf{H g}^{+2}}{\text { Oxidized, }}$ & $\begin{array}{c}\text { Elemental, } \\
\mathbf{H g}^{0}\end{array}$ & Total Hg & \\
\hline \multicolumn{9}{|c|}{ Dryer Mill (1 of 2 ) } \\
\hline \multirow[t]{5}{*}{ S12 } & 1 & $3 / 21$ & $1008-1216$ & 0.020 & $<0.15$ & 1.62 & 1.64 & $1.07 \times 10^{-4}$ \\
\hline & 2 & $3 / 21$ & $1329-1536$ & 0.048 & 0.24 & 1.87 & 2.15 & $1.48 \times 10^{-4}$ \\
\hline & 3 & $3 / 21$ & $1609-1817$ & 0.048 & 1.13 & 1.88 & 3.05 & $2.11 \times 10^{-4}$ \\
\hline & \multicolumn{3}{|l|}{ Mean } & 0.039 & 0.50 & 1.79 & 2.28 & $1.55 \times 10^{-4}$ \\
\hline & \multicolumn{3}{|c|}{ 95\% Confidence Interval } & 0.018 & 0.61 & 0.16 & 0.81 & $0.59 \times 10^{-4}$ \\
\hline \multicolumn{9}{|c|}{ Kettle Calciner (1 of 2 ) } \\
\hline \multirow[t]{5}{*}{ S13 } & 1 & $3 / 21$ & $1118-1234$ & 0.45 & 3.55 & 242 & 246 & $1.88 \times 10^{-3}$ \\
\hline & 2 & $3 / 21$ & $1355-1508$ & 1.28 & 2.32 & 277 & 281 & $2.08 \times 10^{-3}$ \\
\hline & 3 & $3 / 21$ & $1638-1744$ & 1.06 & 3.64 & 287 & 291 & $2.10 \times 10^{-3}$ \\
\hline & \multicolumn{3}{|l|}{ Mean } & 0.93 & 2.96 & 269 & 273 & $2.02 \times 10^{-3}$ \\
\hline & \multicolumn{3}{|c|}{ 95\% Confidence Interval } & 0.49 & 0.84 & 27 & 27 & $1.38 \times 10^{-3}$ \\
\hline \multicolumn{9}{|c|}{ Board Dryer Kiln (1 of 1 ) } \\
\hline \multirow{5}{*}{$\begin{array}{l}\text { S14a } \\
\text { (wet } \\
\text { end) }\end{array}$} & 1 & $3 / 22$ & $0904-1110$ & 0.030 & $<0.13$ & 1.21 & 1.24 & $0.62 \times 10^{-4}$ \\
\hline & 2 & $3 / 22$ & $1220-1426$ & $<0.012$ & 0.26 & 2.21 & 2.47 & $1.40 \times 10^{-4}$ \\
\hline & 3 & $3 / 22$ & $1501-1707$ & $<0.020$ & $<0.16$ & 0.70 & 0.70 & $0.37 \times 10^{-4}$ \\
\hline & \multicolumn{3}{|l|}{ Mean } & 0.021 & 0.18 & 1.37 & 1.47 & $0.80 \times 10^{-4}$ \\
\hline & \multicolumn{3}{|c|}{ 95\% Confidence Interval } & 0.010 & 0.08 & 0.87 & 1.03 & $0.61 \times 10^{-4}$ \\
\hline \multirow{5}{*}{$\begin{array}{l}\text { S14b } \\
\text { (dry } \\
\text { end) }\end{array}$} & 1 & $3 / 22$ & 0904-1109 & $<0.016$ & 0.27 & 0.24 & 0.50 & $0.41 \times 10^{-4}$ \\
\hline & 2 & $3 / 22$ & $1219-1423$ & $<0.015$ & 0.36 & 0.39 & 0.75 & $0.60 \times 10^{-4}$ \\
\hline & 3 & $3 / 22$ & $1502-1705$ & $<0.015$ & $<0.17$ & 0.096 & 0.096 & $0.08 \times 10^{-4}$ \\
\hline & \multicolumn{3}{|l|}{ Mean } & $<0.015$ & 0.27 & 0.24 & 0.45 & $0.36 \times 10^{-4}$ \\
\hline & \multicolumn{3}{|c|}{ 95\% Confidence Interval } & - & 0.11 & 0.16 & 0.37 & $0.30 \times 10^{-4}$ \\
\hline
\end{tabular}

${ }^{*} \mu \mathrm{g} / \mathrm{Nm}^{3}=$ Micrograms per normal cubic meter (dry gas at $32^{\circ} \mathrm{F}$, at as-measured $\mathrm{O}_{2}$ concentration)

$\#_{\mathrm{lb} / \mathrm{h}}=$ Pounds per hour

In the board dryer kiln stacks, the mercury concentrations measured at Wallboard Plant 4 were significantly lower than was measured at Wallboard Plant 1 as part of Task 1 (a mean of approximately $7 \mu \mathrm{g} / \mathrm{Nm}^{3}$ ), but higher than was measured at Wallboard Plant 3 as part of Task 4 (approximately $0.5 \mu \mathrm{g} / \mathrm{Nm}^{3}$ in both stacks).

Comparing the mercury mass emission rate data in Table 8 for the three types of process stacks, the mercury losses from the kettle calciners were over 20 times those from the dryer mill, taking 
into account that there is only one dryer mill but two kettle calciners operating. Considering the sum of the mercury losses from the two stacks on the board kiln, the mercury emissions from the board kiln were about three-fourths of those from the dryer mill, and a factor of more than 30 lower than from the kettle calciners.

\section{Plant Process Data}

Plant process data are summarized in Table 9 for the mill tests and Table 10 for the board-line sampling. Some of the process data collected during the tests have not been reported here due to their proprietary nature. Note that in the mill, solids feed rates are not measured directly, but are controlled on a relative basis by the speed of the solids feeders. The rates shown in Table 9 for the dryer mill and kettle calciner were based on the amount of time it took to fill a stucco surge bin with a reported capacity of 30 tons of product.

Table 9. Task 5 Mill Test Process Conditions

\begin{tabular}{|c|c|c|c|c|}
\hline Date & $3 / 21 / 2006$ & $3 / 21 / 2006$ & $3 / 21 / 2006$ & \\
\hline Time & $1008-1216$ & $1329-1536$ & $1609-1817$ & \\
\hline Ontario Hydro Run & Run 1 & Run 2 & Run 3* & Average \\
\hline Dryer Mill Syn Gyp Feeder Output, \% of full scale & 47 & 45 & 45 & 46 \\
\hline Dryer Mill Burner Output, \% of full scale & 41 & 39 & 37 & 39 \\
\hline Estimated Dryer Mill B Wet Feed Rate, tons/hr & 25 & 25 & 25 & 25 \\
\hline Dryer Mill Dust Collector Outlet Temperature, ${ }^{\circ} \mathrm{F}$ & 167 & 178 & 164 & 170 \\
\hline Kettle \#2 Feeder rpm & 780 & 950 & 980 & 900 \\
\hline $\begin{array}{l}\text { Estimated Kettle Calciner Stucco Production Rate, } \\
\text { tons/hr }\end{array}$ & 9.2 & 9.2 & 9.2 & 9.2 \\
\hline Kettle \#2 Stucco Temperature, ${ }^{\circ} \mathrm{F}$ & 300 & 300 & 300 & 300 \\
\hline
\end{tabular}

Table 10. Task 4 Board-line Test Process Conditions

\begin{tabular}{|l|l|l|l|}
\hline Date & $\mathbf{3 / 2 2 / 2 0 0 6}$ & $\mathbf{3 / 2 2 / 2 0 0 6}$ & $\mathbf{3 / 2 2 / 2 0 0 6}$ \\
\hline Time & $\mathbf{0 9 0 1 - 1 1 1 0}$ & $\mathbf{1 2 2 0 - 1 4 2 6}$ & $\mathbf{1 5 0 1 - 1 7 0 7}$ \\
\hline Board Width, in. & 48 & 48 & 48 \\
\hline Board Thickness, in. & 0.625 & $0.625 / 0.5^{\star}$ & 0.5 \\
\hline Kiln Temperature, ${ }^{\circ} \mathrm{F}$ & Not recorded & 545 & 630 \\
\hline
\end{tabular}

*Product change during run

The process conditions shown in Tables 9 and 10 were used as the basis for mercury balance calculations, as discussed in the following subsection. Note that during board-line Run 1 , the board line was producing 5/8-in. thick wallboard while during Run 3, the standard 1/2-in. thick product was being made. The change was made in the middle or Run 2 . Also there were process upsets during Runs 1 and 2 that led to periods of time where wet wallboard was not being feed to the board dryer kiln. These down times were accounted for in the mercury balance calculations discussed in the following subsection. 


\section{Mercury Balance Results}

Table 11 summarizes the mercury balance data for the mill testing. Details are shown on the mercury balance intermediate calculation results, based on input data taken from previous tables in this report.

Table 11. Task 5 Mercury Balance Results for the Mill Test

\begin{tabular}{|c|c|c|c|c|c|}
\hline Run Number & Run 1 & Run 2 & Run 3 & Mean & 95\% C.I. \\
\hline \multicolumn{6}{|l|}{ Feed to Dryer Mill (Raw Gypsum): } \\
\hline Feed rate, tons/hr & 25 & 25 & 25 & 25 & - \\
\hline Wt\% moisture & 11.4 & 10.9 & 10.4 & 10.9 & \pm 0.5 \\
\hline Hg content, $\mu \mathrm{g} / \mathrm{g}$, dry basis (from Table 3 ) & 0.17 & 0.21 & 0.23 & 0.20 & \pm 0.03 \\
\hline Total Hg to dryer mill, $\mathrm{g} / \mathrm{hr}$ & 3.3 & 4.1 & 4.5 & 4.0 & \pm 0.7 \\
\hline \multicolumn{6}{|l|}{ Dryer Mill Product (Land Plaster): } \\
\hline Dry rate, tons $/ \mathrm{hr}$ & 22 & 22 & 22 & 22 & - \\
\hline Hg content, $\mu \mathrm{g} / \mathrm{g}$ (from Table 3) & 0.14 & 0.19 & 0.20 & 0.18 & \pm 0.04 \\
\hline Total Hg from dryer mill, $\mathrm{g} / \mathrm{hr}$ & 2.7 & 3.8 & 4.0 & 3.5 & \pm 0.8 \\
\hline Measured solids Hg loss rate, $\mathrm{g} / \mathrm{hr}$ & 0.6 & 0.4 & 0.5 & 0.5 & \pm 0.1 \\
\hline $\begin{array}{l}\text { Measured Hg loss rate at stack, lb/hr (from Table } \\
\text { 8) }\end{array}$ & $1.07 \times 10^{-4}$ & $1.48 \times 10^{-4}$ & $2.11 \times 10^{-4}$ & $1.55 \times 10^{-4}$ & $\begin{array}{l} \pm 0.59 x \\
10^{-4}\end{array}$ \\
\hline Measured Hg loss rate at stack, $\mathrm{g} / \mathrm{hr}$ & 0.05 & 0.07 & 0.10 & 0.07 & \pm 0.03 \\
\hline$\% \mathrm{Hg}$ loss across dryer mill, by solids analysis & $18.5 \%$ & $9.3 \%$ & $11.2 \%$ & $12.6 \%$ & $\pm 5.5 \%$ \\
\hline$\% \mathrm{Hg}$ loss across dryer mill, by Ontario Hydro & $1.5 \%$ & $1.6 \%$ & $2.1 \%$ & $1.8 \%$ & $\pm 0.4 \%$ \\
\hline \multicolumn{6}{|l|}{ Land Plaster Feed to Kettle Calciner: } \\
\hline Feed rate, tons/hr & 11 & 11 & 11 & 11 & - \\
\hline Hg content, $\mu \mathrm{g} / \mathrm{g}$ (from Table 3) & 0.15 & 0.20 & 0.20 & 0.18 & \pm 0.03 \\
\hline Total $\mathrm{Hg}$ to kettle calciner, $\mathrm{g} / \mathrm{hr}$ & 1.5 & 1.9 & 2.0 & 1.8 & \pm 0.3 \\
\hline \multicolumn{6}{|l|}{ Product Stucco: } \\
\hline Product rate, tons $/ \mathrm{hr}$, calculated & 9.2 & 9.2 & 9.3 & 9.2 & \pm 0.1 \\
\hline Hg content (as measured), $\mu \mathrm{g} / \mathrm{g}$ (from Table 3) & 0.13 & 0.15 & 0.18 & 0.15 & \pm 0.03 \\
\hline Total Hg from kettle calciner, $\mathrm{g} / \mathrm{hr}$ & 1.0 & 1.3 & 1.5 & 1.3 & \pm 0.3 \\
\hline Measured solids Hg loss rate, $\mathrm{g} / \mathrm{hr}$ & 0.5 & 0.7 & 0.5 & 0.6 & \pm 0.1 \\
\hline $\begin{array}{l}\text { Measured Hg loss rate at stack, Ib/hr (from Table } \\
\text { 8) }\end{array}$ & $1.88 \times 10^{-3}$ & $2.08 \times 10^{-3}$ & $2.10 \times 10^{-3}$ & $2.02 \times 10^{-3}$ & $\begin{array}{l} \pm 0.14 x \\
10^{-3}\end{array}$ \\
\hline Measured $\mathrm{Hg}$ loss rate at stack, $\mathrm{g} / \mathrm{hr}$ & 0.85 & 0.94 & 0.95 & 0.92 & \pm 0.06 \\
\hline $\begin{array}{l}\% \mathrm{Hg} \text { loss across kettle calciner, by solids } \\
\text { analysis }\end{array}$ & $32 \%$ & $35 \%$ & $24 \%$ & $30 \%$ & $\pm 6 \%$ \\
\hline$\% \mathrm{Hg}$ loss across kettle calciner, by Ontario Hydro & $56 \%$ & $49 \%$ & $47 \%$ & $50 \%$ & $\pm 6 \%$ \\
\hline \multicolumn{6}{|l|}{ Mass Balance Closures: } \\
\hline Dryer mill Hg closure, output vs. input, $\%$ & $83 \%$ & $92 \%$ & $91 \%$ & $89 \%$ & $\pm 6 \%$ \\
\hline $\begin{array}{l}\text { Kettle Calciner Hg balance closure, output vs. } \\
\text { input, \% }\end{array}$ & $125 \%$ & $113 \%$ & $123 \%$ & $120 \%$ & $\pm 7 \%$ \\
\hline Overall Mill $\mathrm{Hg}$ balance closure, $\%$ & $116 \%$ & $108 \%$ & $113 \%$ & $112 \%$ & $\pm 5 \%$ \\
\hline
\end{tabular}

The mercury balance data are shown in several ways. First the percentage mercury loss from the gypsum solids being processed is calculated, with that percentage being calculated in two ways: one based on the apparent loss by comparing inlet and outlet process solid sample mercury 
concentrations, and the other based on the inlet process sample concentration versus the Ontario Hydro measurement results for mercury losses from the stacks. The other form of presenting the data is an actual mercury balance, with individual balance closure percentages shown across the dryer mill, kettle calciner, and overall mill. These mercury balances were calculated from the inlet solids mercury concentrations and flow rates, outlet solids mercury concentrations and flow rates, and mercury losses in the flue gases based on the Ontario Hydro results.

The results show that the percentage mercury losses across the dryer mill were low, at about 2\% of the mercury in the raw gypsum based on Ontario Hydro stack results. The solids analyses indicated a higher loss percentage of nearly $13 \%$. For the kettle calciner, the percentage loss based on the Ontario Hydro stack results averaged 50\%, while the loss calculated from the solids analyses averaged only 30\%. The mercury losses measured by the Ontario Hydro method are believed to be more accurate than the losses indicated by solids analyses. The Ontario Hydro results represent a direct measurement of losses, integrated over a one- to two-hour period, whereas the losses by solids analyses are based on the differences between analyses of one feed and product grab sample for each run period.

The mercury balances across the dryer mill show an average of 89\% recovery of the mercury in the wet gypsum feed being accounted for in the land plaster product and stack flue gas. This somewhat low recovery is directly related to the mercury loss by solids analyses being greater than that measured by the Ontario Hydro method. If the two percentage losses were equal, the mass balance would show 100\% closure. Conversely, the balances across the kettle calciner show an average of $120 \%$ recovery of the mercury in the land plaster feed versus the sum of the mercury in the product stucco plus that in the stack flue gas. In this case, the recovery of greater than $100 \%$ is a direct result of the percent loss by solids analysis being less than what is indicated by the Ontario Hydro stack results. However, mercury balance closure within $\pm 20 \%$ of $100 \%$ across an operating, full-scale plant is considered acceptable. The overall mercury balance closure across the mill of $112 \%$ is well within that acceptable range.

It is believed the reason these balance closures are not closer to $100 \%$, and the reason the mercury losses calculated from solids analyses do not compare better with the Ontario Hydro results is because the feed solids mercury concentrations were varying during the day. Thus, the single grab sample from each sampling location in the mill may not have adequately represented the average solids mercury content at each location over the duration of the Ontario Hydro sampling runs.

The Task 5 Ontario Hydro method results show the highest percentage mercury losses in the mill of the five tasks conducted. The previous highest percentage losses had been measured in Task 3, for Wallboard Plant 2 and synthetic gypsum from Power Plant B (bituminous coal, LSFO, fines blow down, SCR in service), which was similar in configuration to the power plant that provided the Task 5 gypsum. Comparing the current results to the previous Task 3 results, the mercury loss percentages across the dryer mill are nearly doubled at Wallboard Plant 4 (1.8\% versus $1.0 \%$ ), but both of these percentages are relatively low. The percentage losses across the kettle calciner were nine percentage points higher than those measured in Task 3 (50\% versus 41\%). 
These results showing relatively high mercury loss percentages across the mill in Tasks 3 and 5 suggest that mercury remaining in gypsum from systems that have a significant fines blow down may be more susceptible to loss in the wallboard process than gypsum from systems without fines blow down.

The results of mercury balance calculations across the board line are shown in Table 12. Fewer details about feed rates are shown in Table 12 than in Table 11 due to the proprietary nature of the wallboard forming process.

Table 12. Task 5 Mercury Balance Results for the Board-line Test

\begin{tabular}{|c|c|c|c|c|c|}
\hline Run Number & Run 1 & Run 2 & Run 3 & Mean & 95\% C.I. \\
\hline \multicolumn{6}{|l|}{$\mathrm{Hg}$ in Feed to Board Line: } \\
\hline $\begin{array}{l}\text { Relative Stucco Feed Rate, \% of highest value } \\
\text { during tests }\end{array}$ & 105 & 102 & 93 & 100 & \pm 7 \\
\hline $\begin{array}{l}\mathrm{Hg} \text { Concentration in Stucco, } \mu \mathrm{g} / \mathrm{g} \text { (dry) } \\
\text { (from Table 5) }\end{array}$ & 0.15 & 0.15 & 0.14 & 0.14 & \pm 0.01 \\
\hline $\mathrm{Hg}$ in Stucco Feed, \% of total $\mathrm{Hg}$ into Board Line & 99.3 & 98.7 & 98.4 & 98.8 & \pm 0.5 \\
\hline $\mathrm{Hg}$ in Water Added, \% of total $\mathrm{Hg}$ into Board Line & 0.0 & 0.0 & 0.0 & 0.0 & - \\
\hline $\mathrm{Hg}$ in Additives, \% of total $\mathrm{Hg}$ into Board Line & 0.7 & 1.3 & 1.6 & 1.2 & \pm 0.5 \\
\hline $\mathrm{Hg}$ in Paper, \% of total $\mathrm{Hg}$ into Board Line & 0.0 & 0.0 & 0.0 & 0.0 & - \\
\hline \multicolumn{6}{|l|}{$\mathrm{Hg}$ in Slurry to Board Forming: } \\
\hline $\begin{array}{l}\text { Hg Concentration in slurry, } \mu \mathrm{g} / \mathrm{g} \text { (dry) } \\
\text { (from Table 5) }\end{array}$ & 0.13 & 0.11 & 0.09 & 0.11 & \pm 0.02 \\
\hline Moisture in Set Up Slurry, wt\% & 22.1 & 28.7 & 30.2 & 27.0 & \pm 4.9 \\
\hline $\begin{array}{l}\text { Hg in Slurry, \% closure with stucco + water + } \\
\text { additives }\end{array}$ & $118 \%$ & $102 \%$ & $85 \%$ & $104 \%$ & $\pm 18 \%$ \\
\hline \multicolumn{6}{|l|}{ Hg in Wet Wallboard: } \\
\hline $\begin{array}{l}\mathrm{Hg} \text { Concentration in Wet Wallboard, } \mu \mathrm{g} / \mathrm{g} \text { (dry) } \\
\text { (from Table 5) }\end{array}$ & 0.13 & 0.11 & 0.10 & 0.12 & \pm 0.01 \\
\hline Moisture in Wet Wallboard, wt\% & 24.7 & 26.4 & 29.6 & 26.9 & \pm 2.8 \\
\hline $\begin{array}{l}\text { Hg in Wet Wallboard, \% closure with stucco + } \\
\text { water + additives + paper }\end{array}$ & $112 \%$ & $106 \%$ & $95 \%$ & $105 \%$ & $\pm 9 \%$ \\
\hline \multicolumn{6}{|l|}{ Hg in Wallboard Product: } \\
\hline $\begin{array}{l}\text { Hg Concentration in Wallboard Product, } \mu \mathrm{g} / \mathrm{g} \text { (dry) } \\
\text { (from Table } 5\end{array}$ & 0.14 & 0.12 & 0.11 & 0.12 & \pm 0.02 \\
\hline \multicolumn{6}{|l|}{ Hg Loss and Balance Closures: } \\
\hline $\begin{array}{l}\text { Measured } \mathrm{Hg} \text { loss rate at stack, lb/hr } \\
\text { (from Table } 8\end{array}$ & $1.02 \times 10^{-}$ & $2.00 \times 10^{-4}$ & $40.45 \times 10^{-4}$ & $1.15 \times 10^{-4}$ & $\begin{array}{l} \pm 0.88 x \\
10^{-4}\end{array}$ \\
\hline $\begin{array}{l}\% \text { Hg Loss Across Board Dryer Kiln, by solids } \\
\text { analysis }\end{array}$ & $-4.6 \%$ & $-1.1 \%$ & $-4.4 \%$ & $-3.4 \%$ & $\pm 2.3 \%$ \\
\hline $\begin{array}{l}\text { \% Hg Loss Across Board Dryer Kiln, by Ontario } \\
\text { Hydro }\end{array}$ & $1.8 \%$ & $2.8 \%$ & $0.6 \%$ & $1.4 \%$ & $\pm 1.2 \%$ \\
\hline Hg Balance Across Board Dryer Kiln, \% & $105 \%$ & $104 \%$ & $105 \%$ & $105 \%$ & $\pm 1 \%$ \\
\hline Overall Board-line Hg Balance, output vs. input, \% & $118 \%$ & $109 \%$ & $100 \%$ & $110 \%$ & $\pm 10 \%$ \\
\hline
\end{tabular}

The results show that mercury losses across the board dryer kiln are relatively low compared to the total mercury content of the wet board, with values averaging 1.4\% loss shown in the Ontario Hydro stack results. The solids analyses results actually show no loss, averaging $-3 \%$ loss (3\% 
gain). As described above for the mill results, the Ontario Hydro results are believed to be more accurate than the loss percentages estimated from grab sample mercury analyses.

The observed mercury balances across the board kiln show good closure, averaging 105\% recovery of the mercury in the wet board in the dry wallboard product and the two kiln stacks. The closures across the overall board line are not quite as good, ranging from $100 \%$ to $118 \%$ and averaging $110 \%$.

At this point in the project, mercury losses have been measured across a board kiln by the Ontario Hydro method three times, as part of Tasks 1, 4, and the current task. The mercury losses measured during the current task lie between the two previous measurements. The losses measured at Wallboard Plant 1 as part of Task 1 showed a mean loss percentage of 1.9\%, while the losses measured at Wallboard Plant 3 as part of Task 4 showed a mean loss percentage of $0.5 \%$.

\section{Summary of Mercury Loss Calculations}

The data collected as during this test were used to calculate an overall percentage mercury loss from the raw gypsum feed during the wallboard production process by two methods. One was to sum the measured losses from the process stacks, as measured by the Ontario Hydro method, and compare that total to the amount of mercury coming into the wallboard plant in the raw gypsum feed. The data on which this calculation was based are found in Tables 8 and 11. The second method was to compare the mercury concentrations in the raw gypsum feed to the concentrations in the dry wallboard product. Data on which this calculation was based are found in Tables 3 and 5 (URS results). Results from these two types of calculations are shown in Table 13.

Table 13. Summary of Task 5 Overall Mercury Loss During Wallboard Production, Calculated by Two Methods

\begin{tabular}{|l|l|l|l|l|l|}
\hline & Run 1 & Run 2 & Run 3 & Mean & $\mathbf{9 5 \%}$ C.I. \\
\hline $\begin{array}{l}\text { Total Hg Loss from Process Stacks by Ontario Hydro } \\
\text { Method, g/h* }\end{array}$ & 1.8 & 2.0 & 2.0 & 2.0 & \pm 0.2 \\
\hline Total Hg to Wallboard Plant, g/hr & 3.3 & 4.2 & 4.6 & 4.0 & \pm 0.7 \\
\hline $\begin{array}{l}\text { Observed Overall Percentage Hg Loss based on } \\
\text { Ontario Hydro Method }\end{array}$ & $46 \%$ & $51 \%$ & $55 \%$ & $51 \%$ & \pm 5 \\
\hline $\begin{array}{l}\text { Hg Concentration in Raw Gypsum Feed to Wallboard } \\
\text { Plant, } \mu \text { g/g }\end{array}$ & 0.17 & 0.21 & 0.23 & 0.20 & \pm 0.03 \\
\hline Hg Concentration in Wallboard Product, $\mu$ g/g & 0.14 & 0.12 & 0.11 & 0.12 & \pm 0.02 \\
\hline $\begin{array}{l}\text { Observed Percentage Hg Loss Across Wallboard } \\
\text { Plant based on URS solids analyses }\end{array}$ & $16 \%$ & $45 \%$ & $51 \%$ & $39 \%$ & $\pm 21 \%$ \\
\hline $\begin{array}{l}\text { Observed Percentage Hg Loss Across Wallboard } \\
\text { Plant based on solids analyses, corrected for Hg } \\
\text { added with additives and paper in board line }\end{array}$ & $17 \%$ & $45 \%$ & $52 \%$ & $40 \%$ & $\pm 21 \%$ \\
\hline
\end{tabular}

*Assumes one dryer mill and two kettle calciner stacks, includes both board dryer kiln stacks

"Includes mercury in raw gypsum feed plus mercury added by additives and paper in the board line 
The mean overall lost percentage by the first method shows $51 \%$ of the plant input mercury out the four process stacks as measured by the Ontario Hydro method. The apparent loss measured by the second method, the change in mercury concentration from the mill feed to the wallboard product is somewhat lower, with a mean loss percentage of $40 \%$ after correcting for mercury added with additives and paper in the board line.

The two methods do not agree well with respect to the percentage mercury loss from the wallboard plant feed. For reasons discussed earlier in this report, it is believed that the mean value of 51\% mercury loss across the wallboard plant calculated by the first method, based on Ontario Hydro results, better reflects the actual losses from this feedstock. The mercury loss percentages calculated by the other approach, based on solids analyses, can be adversely impacted by two effects. One is the fact that the feed and product samples represent grab samples taken at a single point in time during each sampling run. If the feed concentrations change over the course of an Ontario Hydro run, the grab-sample solids analyses may not adequately reflect mercury losses over the entire one- to two-hour Ontario Hydro measurement period. The second possible adverse impact is the effect of analytical variability when comparing two concentration measurement results to quantify a mercury percentage loss. 


\section{CONCLUSION}

The use of synthetic gypsum in making wallboard has long benefited the environment by recycling the FGD gypsum byproduct, decreasing the need to landfill and increasing the sustainable design of the wallboard product. In the future, increasing numbers of FGD systems will be operating in the U.S. in response to EPA's Clean Air Interstate Rule, signed on March 10, 2005, which calls for further reductions in sulfur dioxide emissions from coal-fired power plants. Correspondingly, greater amounts of synthetic gypsum will be produced to either be recycled or land filled. The Clean Air Mercury Rule, signed by EPA on March 15, 2005, takes into account the expectation that significant mercury emissions reductions will be obtained as a "co-benefit" of increased control of $\mathrm{SO}_{2}$ (and $\mathrm{NO}_{\mathrm{X}}$ ) emissions. This study investigates the potential for mercury to be released in the atmosphere when synthetic gypsum material is used as a feedstock for wallboard production.

Task 5 evaluated the use of synthetic gypsum from a limestone forced-oxidation FGD system on a plant that fires Eastern bituminous coal, did not have an SCR in service, and employs gypsum fines blow down. These results indicated that $51 \%$ of the incoming mercury was emitted during wallboard production, as measured by the Ontario Hydro method. These losses were distributed as approximately 1 to $2 \%$ each across the dryer mill and board dryer kiln, and $50 \%$ across the kettle calciner.

The measured mercury losses from Wallboard Plant 4 totaled approximately 2 grams per hour, considering the operation of one dryer mill, two kettle calciners, and one board dryer kiln. Of this total loss, about 4\% was from the dryer mill, 94\% from the kettle calciners, and less than 3\% from the board dryer kiln. The total mercury losses measured amount to less than $0.2 \mathrm{lb}$ of mercury emitted per million square feet of wallboard produced or 0.09 gram of mercury per ton of dry gypsum processed. Based on Task 5 mercury emission results and approximate industry production rates, the wallboard industry would emit less than one ton of mercury compared to the current power industry emissions of 48 tons reported by the Environmental Protection Agency. According to this calculation, the estimated wallboard industry emissions would be about $2 \%$ of current power industry emissions.

The individual results from Tasks 1 through 5 of this project would predict mercury emissions from the wallboard industry ranging from 0.2 to $2 \%$ of current power industry emissions. However, the results from Tasks 1 through 5 still represent a relatively small subset of the power plants, coal types, FGD conditions and wallboard plant conditions corresponding with synthetic gypsum use for wallboard production. Actual U.S. wallboard industry mercury emissions may vary from estimates made based on Task 1 through 5 results.

Of the flue gas streams measured for mercury content by the Ontario Hydro Method in Task 5, the kettle calciner steam stack showed the highest mercury concentrations, with concentrations of 250 to $290 \mu \mathrm{g} / \mathrm{Nm}^{3}$ when reported on a dry gas basis at actual flue gas oxygen concentrations. Because of differences in mass flow rate and moisture content, this mercury concentration cannot be compared to typical concentrations in coal-fired power plant stack flue gases. The kettle steam stack gas was measured to have a very high moisture content of $49 \%$. The mercury concentrations are considerably lower when expressed on a wet flue gas basis, which is the 
condition under which it is actually released into the atmosphere. Furthermore, the flow rate from this kettle calciner steam stack was quite low, over two orders of magnitude lower than the flue gas flow rate from a typical power plant firing bituminous coal. The mercury concentrations in the flue gas from the dryer mill and board dryer kiln were considerably lower, ranging from 2 to $3 \mu \mathrm{g} / \mathrm{Nm}^{3}$ in the dryer mill stack and from $2.5 \mu \mathrm{g} / \mathrm{Nm}^{3}$ down to less than $0.5 \mu \mathrm{g} / \mathrm{Nm}^{3}$ in the two board kiln stacks.

Results are now available from five full-scale wallboard plant tests, conducted as Tasks 1 through 5 of this project. Task 1 tested gypsum from a power plant that fires medium- to highsulfur bituminous coal, has an SCR and a limestone forced oxidation FGD system, and does not employ gypsum fines blow down (the fines remain with the bulk gypsum byproduct). Task 2 tested gypsum from the same power plant but produced while the SCR was not in service (catalyst bypassed). Task 3 tested gypsum from a power plant configuration similar to that tested in Task 1, although with fines blow down from the gypsum byproduct, while Task 4 tested gypsum from a power plant that fires Texas lignite, has a limestone forced oxidation FGD system, no SCR, and no gypsum fines blow down. Finally, Task 5 tested gypsum from a power plant configuration similar to that tested in Task 3 , in that the FGD system employs gypsum fines blow down.

The results from Task 5 proved to be very similar to those from Task 3 . The gypsum mercury concentration were nearly the same, at about $0.2 \mu \mathrm{g} / \mathrm{g}$, and the overall mercury loss percentages were very similar ( $46 \%$ for Task 3 , which included an estimate for the mercury loss across the wallboard dryer kiln, which was not measured by the Ontario Hydro method, versus $51 \%$ for Task 5). The results from these two tasks also showed the highest percentage mercury losses across the wallboard process of the five gypsum/wallboard plant configurations tested. This similarity in results for gypsum from two FGD systems employing gypsum fines blow down suggests a relationship between this aspect of FGD system operation and mercury emissions from the wallboard process. However, it remains a possibility that it is merely coincidence that these two test results are so similar.

In the Task 5 results, as was seen in the Task 1 through 4 results, most of the mercury emissions from the mill were measured to be in the elemental form $\left(\mathrm{Hg}^{0}\right)$. These results are contrary to what was expected at the beginning of this project given that it is predominantly water-soluble oxidized mercury $\left(\mathrm{Hg}^{+2}\right)$ that is removed in wet FGD systems, while elemental mercury is virtually insoluble and not removed at significant percentages. The cause of this phenomenon has not yet been determined either. 


\section{REFERENCES}

1. Marshall, Jessica, Gary Blythe and Mandi Richardson. Fate of Mercury in Synthetic Gypsum Used for Wallboard Production, Topical Report, Task 1 Wallboard Plant Test Results, U.S. Department of Energy, Pittsburgh, PA. Cooperative Agreement Number DE-FC2604NT42080, April 2005.

2. Marshall, Jessica, Gary Blythe and Mandi Richardson. Fate of Mercury in Synthetic Gypsum Used for Wallboard Production, Topical Report, Task 2 Wallboard Plant Test Results, U.S. Department of Energy, Pittsburgh, PA. Cooperative Agreement Number DE-FC2604NT42080, August 2005.

3. Marshall, Jessica, Gary Blythe and Mandi Richardson. Fate of Mercury in Synthetic Gypsum Used for Wallboard Production, Topical Report, Task 3 Wallboard Plant Test Results, U.S. Department of Energy, Pittsburgh, PA. Cooperative Agreement Number DE-FC2604NT42080, August 2005.

4. Marshall, Jessica, Gary Blythe and Mandi Richardson. Fate of Mercury in Synthetic Gypsum Used for Wallboard Production, Topical Report, Task 4 Wallboard Plant Test Results, U.S. Department of Energy, Pittsburgh, PA. Cooperative Agreement Number DE-FC2604NT42080, November 2005.

5. Mercury Stability in FGD Byproducts, EPRI, Palo Alto, CA: 2004. 1004711.

6. Mercury Study Report to Congress Volume III: Fate and Transport of Mercury in the Environment, United States Environmental Protection Agency, EPA-452/R-97-005, December 1997.

7. Standard Test Method for Elemental, Oxidized, Particulate-Bound and Total Mercury in Flue Gas Generated from Coal-Fired Stationary Sources (Ontario Hydro Method), ASTM International, West Conshohocken, PA, June 2002. D 6784 - 02. 